\title{
Exploring high-end scenarios for local sea level rise to develop flood protection strategies for a low-lying delta-the Netherlands as an example
}

\author{
Caroline A. Katsman - A. Sterl • J. J. Beersma • H. W. van den Brink • J. A. Church • \\ W. Hazeleger · R. E. Kopp · D. Kroon • J. Kwadijk • R. Lammersen • J. Lowe • \\ M. Oppenheimer · H.-P. Plag • J. Ridley • H. von Storch • D. G. Vaughan • \\ P. Vellinga - L. L. A. Vermeersen · R. S. W. van de Wal · R. Weisse
}

Received: 24 November 2009 / Accepted: 21 January 2011 / Published online: 24 February 2011

(C) The Author(s) 2011. This article is published with open access at Springerlink.com

\begin{abstract}
Sea level rise, especially combined with possible changes in storm surges and increased river discharge resulting from climate change, poses a major threat in low-lying river deltas. In this study we focus on a specific example of such a delta: the Netherlands. To evaluate whether the country's flood protection strategy is capable of coping with future climate conditions, an assessment of low-probability/highimpact scenarios is conducted, focusing mainly on sea level rise. We develop a plausible high-end scenario of 0.55 to $1.15 \mathrm{~m}$ global mean sea level rise, and 0.40 to $1.05 \mathrm{~m}$ rise on the coast of the Netherlands by 2100 (excluding land subsidence), and more than three times these local values by 2200. Together with projections for changes in storm surge height and peak river discharge, these scenarios depict a complex, enhanced flood risk for the Dutch delta.
\end{abstract}

C. A. Katsman ( $ه)$

Royal Netherlands Meteorological Institute (KNMI), Global Climate Division,

P.O. Box 201, 3730 AE De Bilt, The Netherlands

e-mail: caroline.katsman@knmi.nl

A. Sterl · J. J. Beersma · W. Hazeleger

KNMI, De Bilt, The Netherlands

H. W. van den Brink

Meteo Consult BV, Wageningen, The Netherlands

J. A. Church

Centre for Australian Weather and Climate Research,

A partnership between CSIRO and the Bureau of Meteorology,

and the Antarctic Climate and Ecosystems CRC, Hobart, Australia

R. E. Kopp · M. Oppenheimer

Woodrow Wilson School of Public and International Affairs and Department of Geosciences,

Princeton University, Princeton, NJ, USA 


\section{Introduction}

For a low-lying delta like the Netherlands, the possible impacts of sea level rise induced by climate change are a major concern. Global mean sea level rise is mainly caused by steric changes (changes in in ocean density, predominantly due to thermal expansion), and eustatic changes (changes in ocean mass), due to mass changes in small continental glaciers and ice sheets, and in the Antarctic Ice Sheet and Greenland Ice Sheet.

In the Fourth Assessment Report of the Intergovernmental Panel on Climate Change (IPCC AR4, Meehl et al. 2007a), a global mean sea level rise of 0.18-0.59 m for 2090-2100 with respect to 1990 was projected in response to various scenarios for greenhouse gas emissions. These results are based on detailed assessment of thermal expansion of the oceans from climate models, melting of mountain glaciers from scaling of observations to atmospheric temperature rise, and ice sheet surface mass balance changes and dynamic response from ice sheet models and the extrapolation of recent observations (Meehl et al. 2007a). In IPCC AR4, it is further stated that an additional, temperature-dependent contribution of up to about $0.1-0.2 \mathrm{~m}$ (referred to as the "scaled-up ice sheet discharge") could arise from the ice sheets if the recently observed acceleration in discharge continues (IPCC AR4, Ch. 10.6.5). When this

D. Kroon

School of GeoSciences, University of Edinburgh, Edinburgh, Scotland

D. Kroon

Free University, Amsterdam, The Netherlands

J. Kwadijk

Deltares, Delft, The Netherlands

R. Lammersen

Rijkswaterstaat Waterdienst, Lelystad, The Netherlands

J. Lowe · J. Ridley

Met Office Hadley Centre, Met Office, UK

H.-P. Plag

Nevada Bureau of Mines and Geology and Seismological Laboratory, University of Nevada, Carson City, NV, USA

H. von Storch · R. Weisse

GKSS Research Center, Institute for Coastal Research, Geesthacht, Germany

D. G. Vaughan

British Antarctic Survey, Natural Environment Research Council, Cambridge, UK

P. Vellinga

Alterra, Wageningen University and Research Centre, Wageningen, The Netherlands

L. L. A. Vermeersen

DEOS, Delft University of Technology, Delft, The Netherlands

R. S. W. van de Wal

Institute for Marine and Atmospheric Research, Utrecht University, Utrecht, The Netherlands 
contribution is added, the projected range in global mean sea level rise becomes $0.18-0.76 \mathrm{~m}$.

After publication of IPCC AR4 (Meehl et al. 2007a), larger estimates for the future contributions from the Greenland and Antarctic ice sheets (Pfeffer et al. 2008) and glaciers and ice caps (Meier et al. 2007; Pfeffer et al. 2008) have been published, which do attempt to capture the contributions due to fast ice dynamics. Based on kinematic constraints on ice flow velocities, Pfeffer et al. (2008) presented a low and a high estimate for global mean sea level rise in 2100 of 0.8 and $2.0 \mathrm{~m}$, respectively. Severe scenarios for global mean sea level rise have also been proposed based on simple models tuned to observed sea-level trends (e.g., Rahmstorf 2007a; Grinsted et al. 2009; Vermeer and Rahmstorf 2009; Jevrejeva et al. 2010). The socalled semi-empirical models on which these scenarios are based assume a simple relationship that connects observed global sea level rise to observed global mean surface temperature, which is then used to predict future sea level rise based on future global temperature scenarios from IPCC AR4. The resulting projections for 2100 also range up to about $2 \mathrm{~m}$.

A scenario for global mean sea level rise does not suffice when one wants to evaluate a country's flood protection strategy, since local sea level changes can deviate substantially from the global mean. This is illustrated by the fact that over the past 15 years, satellites have measured a global mean sea level rise at a rate of about 3 $\mathrm{mm} / \mathrm{yr}$, while over that period, local changes varied from roughly -10 to $+10 \mathrm{~mm} / \mathrm{yr}$ (e.g., Milne et al. 2009; Cazenave and Nerem 2004). Although this recently observed pattern is certainly affected by decadal variability on the relatively short altimeter time series, we cannot expect future sea level change to be spatially uniform either (Milne et al. 2009).

Two local effects are important to take into account when developing a scenario for local sea level rise. First, steric sea level changes due to variations in ocean temperature and salinity display large spatial variations. Although in many places local thermosteric changes are the most important (see for example Bindoff et al. 2007, Fig. 5.15b), changes in ocean salinity can give rise to substantial local sea level variations as well (Antonov et al. 2002). These local steric changes are closely linked to ocean circulation changes, as the latter are driven by local density gradients (Levermann et al. 2004; Landerer et al. 2007; Yin et al. 2009). Second, melt water released from land-ice masses will not be distributed evenly over the oceans, due to the elastic deformation of the solid Earth and gravitational and rotational changes induced by the accompanying change in mass distribution (e.g., Milne et al. 2009).

Most scenarios for sea level rise present a range for the likely changes. In order to develop adequate flood protection strategies, knowledge of high-impact/lowprobability sea level change scenarios is required, for the specific region of interest and a range of (long) time horizons. In this study, we develop such a high-end scenario for local sea level rise along the Dutch coast for the years 2100 and 2200 , by estimating high-end contributions for each of the components contributing to local sea level change mentioned above, based on the outcomes of climate models and simple models, and on expert judgment. The applied methodology follows the approach taken by Katsman et al. (2008b) while developing a scenario for the likely range of local sea level rise along the coast of the Netherlands. The high-end scenario presented here is part of an assessment exploring the high-end climate change scenarios for flood protection of the Netherlands (Vellinga et al. 2008) carried out 
at the request of a Dutch state commission (Kabat et al. 2009). The accompanying assessment of future storm surge conditions (Sterl et al 2008a; Sterl et al. 2009) and peak discharge of river Rhine (Beersma et al. 2008) are discussed briefly at the end of the paper.

The paper is structured as follows. The methodology is described shortly in Section 2. In Section 3, our high-end scenario for global mean sea level rise for 2100 is presented. Next, the accompanying high-end projection for local sea level rise along the Dutch coast is discussed (Section 4). Section 5 focuses on the approximate longterm scenarios for global mean sea level rise and local sea level rise for the year 2200. Paleoclimatic evidence of (rates of) global mean sea level rise during the Last Interglacial stage (Section 6) are used to put the high-end scenarios into perspective. Section 7 focuses on the implications for flood protection of the Netherlands arising from the combined effects of local sea level rise, possible changes in storm surge height, and increased river discharge due to climate change.

\section{Methodology}

To arrive at a high-end scenario for local sea level rise for the Netherlands, we first estimate separate high-end contributions for the processes that dominate the global mean changes:

- global mean thermal expansion of the ocean (Section 3.1);

- mass changes of small continental glaciers and ice caps (GIC, Section 3.2);

- mass changes of the Antarctic Ice Sheet (AIS, Section 3.3.1) and

- mass changes of the Greenland Ice Sheet (GIS, Section 3.3.2).

For this, we use the outcomes of a suite of coupled climate models (Meehl et al. 2007b), simple scaling models (e.g., van de Wal and Wild 2001; Rahmstorf 2007a; Katsman et al. 2008b), and expert judgment where appropriate models are lacking. The resulting high-end scenario for global mean sea level rise is compared to other recent high-end estimates (Section 3.4). Subsequently, local effects are considered (Section 4). The local steric contribution is also obtained from an analysis of the suite of climate model results (Meehl et al. 2007b). In addition, the global mean contributions resulting from land-based ice mass changes are translated to local contributions taking into account the gravity-elastic effects (Milne et al. 2009; Mitrovica et al. 2001; Plag and Juettner 2001).

In IPCC AR4, scenarios for sea level rise are presented categorized by emission scenario. However, for sea level rise, the spread in the projections due to different emission scenarios is smaller than the spread displayed by individual climate models driven by the same emission scenario (e.g., Fig. 10.33 in IPCC AR4). To tie the different scenarios to elementary underlying assumptions, previously published climate scenarios for the Netherlands (van den Hurk et al. 2006, 2007) are not linked to specific emission scenarios, but to the projected increase in global mean atmospheric temperature. In this study, we adopt the same strategy, also to facilitate communication of the results to the Dutch public. For most contributions, we deduce a simple dependence on the global mean atmospheric temperature rise $\Delta T_{\text {atm }}$ from model simulations and/or observations. Exceptions are the high-end contributions of AIS and GIS due to fast ice dynamics (Sections 3.3.1 and 3.3.2). 
It is not yet properly understood what physical processes are responsible for the recently observed contributions, but observations point to internal ice dynamics and (changes in) local ocean temperatures rather than ice surface temperatures as primary controllers of recent dynamical changes (e.g., Holland et al. 2008; Jenkins et al. 2010; Straneo et al. 2010). For all other components we consider a range in global mean temperature rise of $\Delta T_{\text {atm }}=2-6 K$ in 2100, similar to the 'likely range' for the A1FI projections in IPCC AR4. For the temperature evolution we use scaled versions of the SRES B1 and A2 scenarios that are non-linear in time. For the low end of the range, it is assumed that the temperature curve flattens in the second half of the twenty-first century (similar to the curve for the B1 scenario in Fig. SPM-5 of IPCC AR4) by defining that two-thirds of the temperature rise is already achieved in 2050. In contrast, for the high end of the range, it is assumed that the rate of temperature rise increases over the course of the twenty-first century (similar to the A2 scenario) by defining that only one-third of the rise is achieved in 2050. A range of $\Delta T_{\mathrm{atm}}=2.5-8 \mathrm{~K}$ (Lenton 2006) is used for the scenario for 2200 .

All high-end estimates for the components contributing to sea level rise presented in this paper contain uncertainties, as a result of the applied range in $\Delta T_{\text {atm }}$ and due to model uncertainties and our incomplete understanding of the underlying process itself (Katsman et al. 2008a, p.16-17). Therefore, for all components a range is given. To arrive at a projection for the total local sea level rise, we sum the median values of the individual contributions and sum their uncertainties quadratically rather than adding the extremes of all ranges. This approach assumes that the uncertainties are independent, which is appropriate when the contributions are distinguished based on the different physical processes causing them (i.e., ocean warming, dynamical ice sheet changes) as is done here. In contrast, contributions that can be attributed to the same process need to be added by summing the extremes of all ranges, assuming that these contributions are perfectly correlated. This is how the dynamical ice sheet contributions from the Amundsen Sea Embayment on Antarctica and from and marine-based glaciers in East Antarctica are treated (Section 3.3.1, Table 2), for example. When the contribution of the first is underestimated because of inaccurate prescriptions of certain processes involved, it is likely that this holds for the latter contribution as well.

Our lack of knowledge of some of the relevant responses of components of the climate system affecting sea level change to greenhouse gas emissions leads to a wide range of sea level projections. We refrain from assigning a likelihood to this high-end scenario because of the limits of current knowledge. The outcome should therefore be taken as indicative of what is-according to our expert judgment and based on the current level of scientific understanding - a plausible high end and longer time frame range of future sea level change scenarios rather than what is most likely. It is by no means guaranteed that these high-end scenarios will remain valid as science progresses, that we bound the possibilities, or that the scenarios are agreed upon by the entire scientific community.

\section{Global mean sea level rise in $\mathbf{2 1 0 0}$}

To explore the high end of possible sea level rise scenarios, we first compute the separate contributions to global mean sea level rise in 2100 with respect to the year 1990. 


\subsection{Global mean thermal expansion}

Most sea level projections available (Meehl et al. 2007b) do not cover the high end of the above-mentioned temperature range for the A1FI scenario $\left(\Delta T_{\mathrm{atm}}=\right.$ $2-6 \mathrm{~K})$. We therefore estimate global mean thermal expansion by applying two alternative idealized scaling relations for the expansion and the rise in global mean atmospheric temperature to the ensemble of available climate model simulations for the twenty-first century (see Section 5.3 in Katsman et al. 2008a, for details). The first scaling method uses a linear relation between thermal expansion and atmospheric temperature rise for the year 2100 (Katsman et al. 2008b), the second applies a linear relation between the rate of global mean thermal expansion and atmospheric temperature rise as the starting-point (Rahmstorf 2007a). Because of their simplicity, both approaches have their limitations in particular when applied to the high end of the scenario range (large atmospheric temperature rise). The semi-empirical approach (Rahmstorf 2007a) was criticized when it was applied to calculate future sea level rise based on observations of sea level rise and atmospheric temperature rise observed in the twentieth century (Holgate et al. 2007; Schmith et al. 2007; Rahmstorf 2007b, see also Section 3.4). Here, it is applied is in a much more constrained setting. Rather than extrapolating over time, we use it to extend the atmospheric temperature range that is considered by exploiting the relation between atmospheric temperature and sea level rise found in climate model simulations for that same period (the twenty-first century).

The two scaling approaches yield similar best estimates, but with a slightly larger uncertainty for the Rahmstorf (2007a) approach. The final estimate for the contribution of global mean thermal expansion is taken as the average of the ranges obtained with the two methods. The approach yields a contribution to global mean sea level rise of 0.12 to $0.49 \mathrm{~m}$ in 2100 (Fig. 1, Table 1). This is slightly wider than the range of

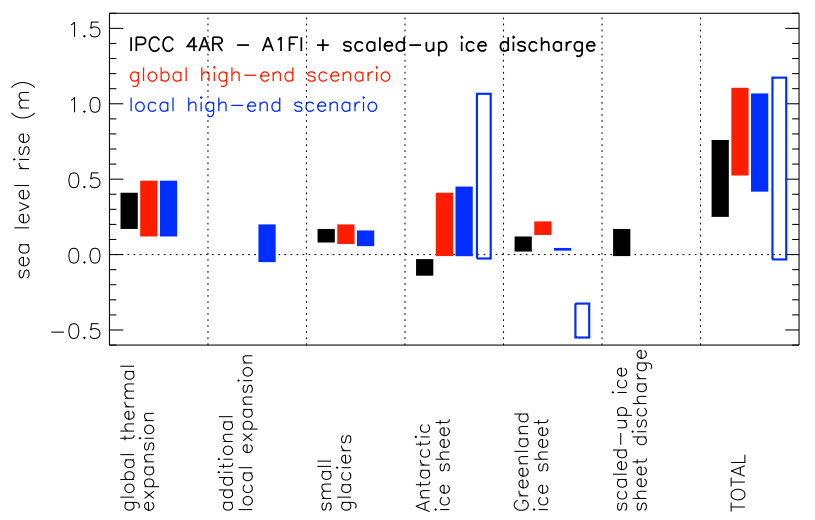

Fig. 1 Ranges for individual contributions and total high-end scenarios for sea level rise for 2100 from various studies (black: global sea level rise for the A1FI scenario in IPCC AR4, including scaled-up ice discharge; red: high-end scenario for global mean sea level rise; blue: high-end scenario for local sea level rise along the Dutch coast (scaling factors used to translate the global mean contributions from land ice masses to local variations are (solid bars): AIS =1.1; GIS =0.2, based on Mitrovica et al. (2001); (open bars): AIS = 2.6; GIS = -2.5, based on Plag and Juettner (2001); see also Section 4). Exact numbers are given in Table 1 
Table 1 Overview of all estimated contributions and the total high-end projections for 2100 assessed here and displayed in Fig. 1 (in $\mathrm{m}$ )

\begin{tabular}{lcccc}
\hline & $\begin{array}{l}\text { Global A1FI } \\
\text { scaled-up ice } \\
\text { discharge } \\
\text { (IPCC AR4) }\end{array}$ & $\begin{array}{l}\text { Global } \\
\text { high-end } \\
\text { (this paper) }\end{array}$ & $\begin{array}{l}\text { Along the Dutch coast, } \\
\text { high-end (this paper) }\end{array}$ \\
\hline Global mean expansion & $0.17-0.41$ & $0.12-0.49$ & $0.12-0.49$ & $0.12-0.49$ \\
Local expansion & - & - & $-0.05-0.2$ & $-0.05-0.2$ \\
Small glaciers & $0.08-0.17$ & $0.07-0.20$ & $0.05-0.16$ & $0.05-0.16$ \\
Antarctic ice sheet & $-0.14--0.03$ & $-0.01-0.41$ & $-0.01-0.45$ & $-0.03-1.07$ \\
Greenland ice sheet & $0.02-0.12$ & $0.13-0.22$ & $0.03-0.04$ & $-0.55--0.33$ \\
Scaled-up ice discharge & $-0.01-0.17$ & - & - & - \\
Terrestrial water storage & $0.0-0.04$ & - & - & - \\
Total & $0.25-0.76$ & $0.55-1.15$ & $0.40-1.05$ & $-0.05-1.15$ \\
\hline
\end{tabular}

Given are the high-end values for global mean sea level rise, the corresponding contributions for the A1FI scenario including the scaled-up ice discharge (IPCC AR4, Table 10.7), and the high-end values for local sea level rise along the Dutch coast (two different sets of scaling factors are used to translate the global mean contributions from land ice masses to local variations; left: numbers based on Mitrovica et al. (2001), right: based on Plag and Juettner (2001); see Section 4 for details). The final numbers assessed in this study are rounded off to $0.05 \mathrm{~m}$

0.17 to $0.41 \mathrm{~m}$ reported in IPCC AR4 for the A1FI emission scenario (Table 10.7). The latter is obtained by scaling climate model results for the A1B scenario with a factor deduced from intermediate complexity models (IPCC AR4, App. 10.A, p. 844).

\subsection{Glaciers and ice caps (GIC)}

The contribution from glaciers and ice caps (GIC) to global mean sea level rise is calculated using the same scaling approach applied in IPCC AR4 (their Section 10.6.3.3. and Appendix 10.A, p. 844). It builds on the approximate linear relationship between the rate of sea level rise from the world's glaciers and ice caps (excluding those in Antarctica and Greenland) and global mean atmospheric temperature estimated from observations (van de Wal and Wild 2001). It takes into account the decline of the temperature sensitivity of the mass balance during glacier retreat, as the most sensitive areas are ablated most rapidly. It also accounts for the decline in glacier area as volume is lost. To include contributions from small glaciers surrounding GIS and AIS, the results of theglacier model are increased by $20 \%$. Note that this approach is expected to be less accurate further into the future, as greater area and volume is lost. When it is applied to a temperature range $\Delta T_{\mathrm{atm}}=2-6 \mathrm{~K}$, it yields a range of 0.07 to $0.20 \mathrm{~m}$ (Fig. 1 , Table 1 ).

To arrive at this estimate, we used a range of $0.15 \mathrm{~m}$ to $0.60 \mathrm{~m}$ sea level equivalent for the present-day global GIC volume (excluding those on Antarctica and Greenland). This encompasses the range of uncertainties spanned by the estimates published by Ohmura (2004), Raper and Braithwaite (2005), Dyurgerov and Meier (2005) and Radic and Hock (2010) and the ranges used in the second and third IPCC Assessment Reports (Houghton et al. 1995, 2001). The higher estimate by Radic and Hock (2010) was not available at the time IPCC AR4 and Vellinga et al. (2008) were 
published. For the projections for 2100, the outcome of the glacier model appears not very sensitive to the value of the present-day GIC volume that is assumed. When the Radic and Hock (2010) estimate is omitted (i.e., using a range in GIC volume of $0.15-0.37 \mathrm{~m}$ and keeping all other parameter ranges fixed) a very similar contribution of 0.07 to $0.18 \mathrm{~m}$ is obtained (Katsman et al. 2008a, Section 2.2.2 on p. 19). Not surprisingly, this range is in turn almost the same as the A1FI estimate in IPCC AR4 (0.08-0.17 m). Alternatively, when the estimate for the present-day GIC volume including the glaciers surrounding GIS and AIS by Dyurgerov and Meier (2005) ( $0.72 \mathrm{~m}$ sea level equivalent) is used in the calculations (omitting the upscaling of the final results by $20 \%$ ), we also obtain a range of 0.07 to $0.20 \mathrm{~m}$.

The GIC contributions resulting from the scaling relation are within a few centimeters of the independent estimate by Meier et al. (2007). Taking into account dynamic processes, like the thinning and retreat of marine-terminating glaciers, they present an estimated contribution of 0.10 to $0.25 \mathrm{~m}$ to sea level rise by 2100 due to GIC mass loss. The low scenario of Pfeffer et al. (2008) is another independent estimate, based on the assumption that the observed acceleration of mass loss is maintained at the present rate. It is assessed at 0.17 to $0.24 \mathrm{~m}$, again in line with our estimate.

Our estimate is considerably smaller than the high scenario of $0.55 \mathrm{~m}$ in Pfeffer et al. (2008). In this high scenario, it is assumed that the dynamic discharge of all marine-terminating glaciers rapidly accelerates by an order of magnitude over a period of 10 years, and that this maximum discharge rate is then maintained until 2100. It can be questioned whether such a scenario can become reality. First, as Pfeffer et al. (2008) discuss, it requires a dramatic increase in glacier discharge rate by an order of magnitude increase. A clear justification for this magnitude is lacking. Up till now, such increased glacier speeds have not been observed, not even for shorter periods. The largest observed increases (Joughin et al. 2004; Howat et al. 2007) involve a doubling of the speed rather than an order of magnitude increase. Second, if such high discharge rates were to occur, it is likely that several tidewater glaciers will retreat above sea level over time, which eliminates the ocean-ice interaction that is thought to be at least partly responsible for the rapid increases in discharge envisioned (e.g., Nick et al. 2009). This retreat would thus result in a consequent reduction in discharge. In our view, this negative feedback makes it unlikely that these maximum discharge rates assumed by Pfeffer et al. (2008) can be maintained during the entire twenty-first century.

\subsection{Ice sheet contributions}

The high-end contributions from AIS and GIS are the most uncertain components. The mass of ice grounded on land in these ice sheets can change as a result of changes in surface mass balance (the mean sum of snow and frost accumulation, and evaporation/sublimation) or in the flux of ice leaving the grounded ice sheet and entering the ocean (either as floating ice, or as melt water). The former is largely a response to atmospheric climate change, while the latter will be a complex response to atmospheric and oceanographic forcings and internal changes in the ice sheet. Our understanding of recently observed dynamic ice sheet behavior (e.g., Alley et al. 2008; Joughin et al. 2008a; Pritchard et al. 2009; Velicogna 2009) is limited. Partly because of this complexity and partly due to a lack of long-term observational 
data, there is a recognition that the present generation of ice sheet models may not adequately simulate the likely changes in ice flux. The key difference between the ice sheet contributions presented here and those in IPCC AR4 is a reassessment of this dynamical contribution based on recent observations and expert judgment. The estimates of changes to the surface mass balance are identical to those of IPCC AR4.

The most vulnerable parts of ice sheets are thought to be the so-called marine ice sheets: ice sheets that rest on bed rock that is below sea level and slopes downwards from the margin to the interior (e.g., Mercer 1978; Vaughan 2008). There is a possibility that positive feedbacks in a marine ice sheet system could lead to a runaway "collapse" of the ice sheet, which would stop only where the retreat encountered a rising bed slope. In essence, the theory of marine ice-sheet instability is that a small inland migration of the ice sheet grounding line would lead to an acceleration of ice-flow out of the ice sheet. This would mean that the input to the ice sheet (primarily through snowfall) becomes insufficient to match the loss from the ice sheet (by melting into the oceans, and iceberg calving), causing a further migration of the grounding line inland and further exacerbate the effect until the retreating grounding line encountered a rising bed slope. The timescale over which such a collapse might occur is not well understood but for large sections of an ice sheet, would probably not run to completion on less than multi-century scales (see also Katsman et al. 2008a, Appendix I-b).

Today, there are a few examples of marine ice sheets on Earth. The largest covers the majority of West Antarctica (Bamber et al. 2009), although a few glaciers in East Antarctica also have large catchment basins below sea level (Pritchard et al. 2009). In Greenland, there is only one glacier basin, that of Jacobshavn Isbrae at the west coast, that appears to contain a similar prominent inland slope, and could potentially display the marine ice sheet instability mechanism. For Petermann glacier in the north it is unclear whether the same mechanism can occur. A comparison of the subglacial topography from each of these basins, as well as recent observations of changes in the ice, suggest that the strongest inland bed slope, and probably the strongest tendency to instability, exists in that portion of the West Antarctic Ice Sheet which drains into the Amundsen Sea-the so-called Amundsen Sea Embayment (Vaughan 2008).

\subsubsection{Antarctic Ice Sheet (AIS)}

Figure 2 shows a compilation of observations of mass change in Antarctica, several of which were not available at the time of publication of IPCC AR4, providing support for the approach taken at that time. At present, observations support the view that the West Antarctic Ice Sheet (WAIS) is losing mass at a significant rate (Fig. 2a). There is little evidence for accelerated mass change in East Antarctica (Fig. 2b), which consequently leads to a change in total Antarctic ice volume (Fig. 2c) dominated by West Antarctica (see also, e.g., Allison et al. 2009).

Our high-end estimate for the contribution to global mean sea level rise from AIS is based on plausible contributions from three areas of Antarctica that are showing signs of change and/or are thought to be vulnerable to marine ice sheet instability:

1. the Amundsen Sea Embayment (ASE) in West Antarctica, 
a

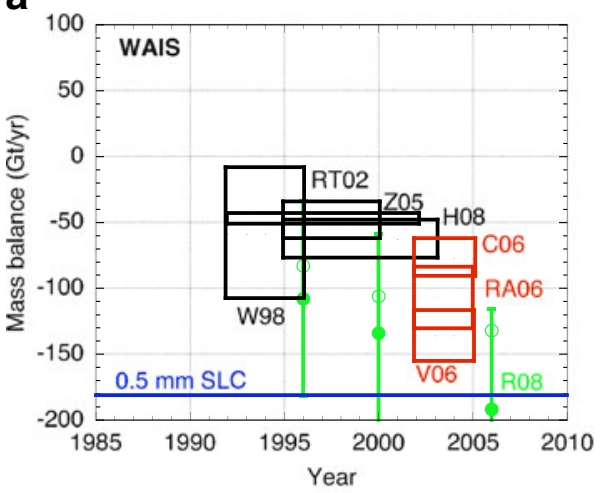

b

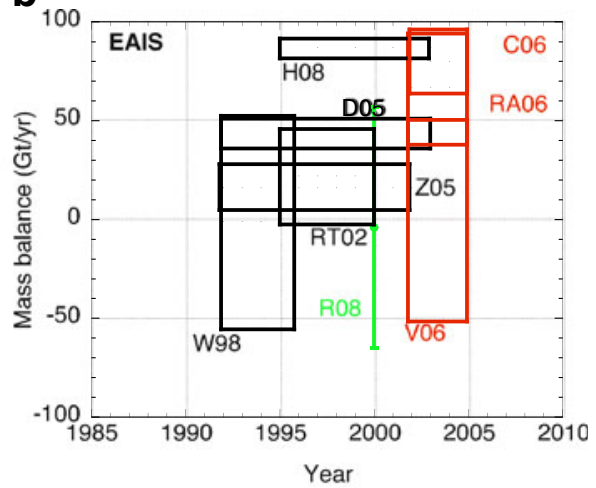

C

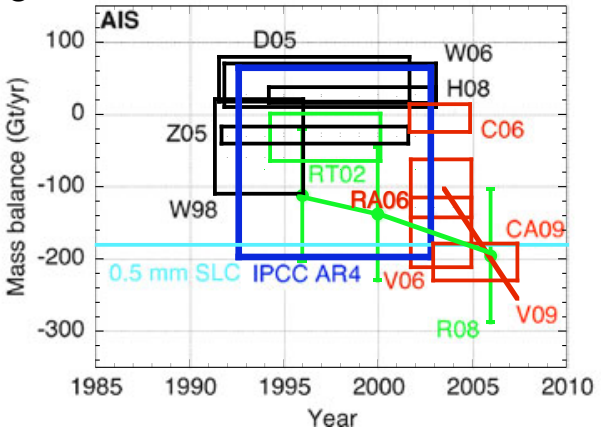

Fig. 2 Various estimates of the mass balance of the a West Antarctic Ice Sheet (WAIS), b East Antarctic Ice Sheet (EAIS) and c Antarctic Ice Sheet (AIS), inferred from green-Insar measurements of ice velocity; red-gravitational measurements (GRACE); black-radar altimetry [C06: Chen et al. 2006; CA09: Cazenave et al. 2009; D05: Davis et al. 2005; H08: Helsen et al. 2008; R08: Rignot et al. 2008; RA06: Ramillien et al. 2006; RT02: Rignot and Thomas 2002; V06: Velicogna and Wahr 2006b; V09: Velicogna 2009; W98: Wingham et al. 1998; W06: Wingham et al. 2006; Z05: Zwally et al. 2005]. The blue boxes indicate the estimate presented in IPCC AR4

2. the three marine-based glacier basins in East Antarctica that are showing recent thinning (Pritchard et al. 2009): Totten Glacier, the glacier which feeds Cook Ice Shelf around $150 \mathrm{E}$, and Denman Glacier (EAIS-g) and

3. the northern Antarctic Peninsula (n-AP), an area that has suffered recent increases in atmospheric temperature, increased glacier melt, glacier retreat, and glacier acceleration (e.g., Cook et al. 2005).

A modest scenario and a severe scenario are developed, which serve as the lower and upper end of the high-end projection for the contribution of AIS to global mean sea level rise. The modest scenario is obtained by assuming a continuation of the recently observed increase in the glacier velocities in ASE and EAIS-g, and of the observed melting and glacier flow in the n-AP. We could characterize this modest scenario as not implying any particularly extreme behavior. The severe scenario is based on an emerging collapse of the ASE and EAIS-g as a result of marine ice sheet 
Table 2 Summarized rationale for the estimated high-end contribution from AIS to global mean sea level rise for 2100 (in m)

\begin{tabular}{|c|c|c|c|c|}
\hline Area & Modest scenario & $\begin{array}{l}\text { Sea level } \\
\text { rise }(\mathrm{m})\end{array}$ & Severe scenario & $\begin{array}{l}\text { Sea level } \\
\text { rise }(\mathrm{m})\end{array}$ \\
\hline$\overline{\mathrm{ASE}}$ & $\begin{array}{l}\text { Continued observed } \\
\text { (acceleration of) } \\
\text { discharge }\end{array}$ & 0.06 to 0.09 & $\begin{array}{l}\text { Ice loss increases } \\
\text { to eight times } \\
\text { the balance value }\end{array}$ & 0.25 \\
\hline EAIS-g & $\begin{array}{l}\text { Ratio current/future } \\
\text { discharge as } \\
\text { for ASE }\end{array}$ & 0.01 & $\begin{array}{l}\text { Ice loss increases } \\
\text { analogous to ASE }\end{array}$ & 0.19 \\
\hline \multirow[t]{2}{*}{$\mathrm{n}-\mathrm{AP}$} & $\begin{array}{l}\text { Increased glacier } \\
\text { acceleration } \\
\text { and run-off }\end{array}$ & 0.0 to 0.05 & $\begin{array}{r}50 \% \text { of available } \\
\text { ice lost by } 2100\end{array}$ & 0.05 \\
\hline & $\begin{array}{l}\text { Accumulation } \\
\text { change }\end{array}$ & -0.08 & $\begin{array}{l}\text { Accumulation } \\
\text { change }\end{array}$ & -0.08 \\
\hline Total & & -0.01 to 0.07 & & 0.41 \\
\hline
\end{tabular}

The final high-end contribution of -0.01 to $0.41 \mathrm{~m}$ spans the modest and severe scenarios

instability (see above). In addition, accelerating melting and glacier flow on the n-AP is assumed.

Modest scenario The modest scenario (Table 2) is based on a continuation of the recently observed changes in the three areas considered (see also Katsman et al. 2008a, Section 5.4.1). The net imbalance that is observed in Pine Island Glacier (the best-measured glacier in the ASE) is around -50\% (Thomas et al. 2004), meaning that about $50 \%$ more ice is now leaving the glacier-basin than is being replaced by snow. Its velocity increased by around 50\% in 30 years (Rignot and Thomas 2002; Joughin et al. 2003). The change in ASE discharge suggests a growing imbalance and an increasing contribution to sea level rise. The estimate for the total contribution of ASE to sea level rise for the period 2000-2100 presented in Table 2 assumes either a continuation of the recent imbalance to 2100 (low end) or a continued acceleration in discharge for ASE at the rate of $1.3 \%$ per year observed over the last decade (Rignot et al. 2008). Although this is a substantial extrapolation and implies mass loss from the ASE catchment, it does not represent a major change in the regime of the ASE ice sheet (Rignot et al. 2008). Flow velocities achieved by 2100 under this scenario (around three to five times the balance velocities) are not unrealistically large. They are comparable to those seen on Jakobshavn Isbrae on GIS prior to its recent acceleration (e.g., Joughin et al. 2004; Rignot and Kanagaratnam 2006).

Accelerated ice stream discharge, but with lower rates of thinning, has been observed across the basins of three East Antarctic glaciers (e.g., Pritchard et al. 2009). These glaciers also have a marine character and may exhibit similar vulnerabilities as ASE. The total flux of these glaciers is estimated to be 121 Gigaton per year (Gt/yr), which is a little less than that of the ASE basins. It seems reasonable to assume that these basins could make a similar, but probably slower, contribution up to 2100. Insufficient data exist to allow an extrapolation similar to that done for ASE. A simple scaling relationship (Katsman et al. 2008a, Section 5.4.1) has therefore been used to arrive at the estimate in Table 2.

The further loss of ice shelves around the Antarctic Peninsula, related glacier acceleration, and increased runoff from melt, are all likely consequences of continued warming on the n-AP. At present the contributions from the latter two processes 
appear to be roughly equal. The only published estimates for the future are for the contribution from increasing melt water runoff (Vaughan 2006) for 2050. If we assume, without strong justification, that glacier acceleration (due to both ice-shelf loss, and acceleration of tidewater glaciers) increases similarly, the total contribution is 0.0 to $0.05 \mathrm{~m}$ in the period 2000-2100 (Table 2).

In summary, under this modest scenario we see AIS contributing around 0.07 to $0.15 \mathrm{~m}$ to global sea level rise by 2100 , as a consequence of changing ice dynamics. To account for the projected increase in accumulation over Antarctica we reduce this estimate by $0.08 \mathrm{~m}$ (average for the A1FI scenario, Table 10.7 of IPCC AR4), and arrive at a net total contribution of -0.01 to $0.07 \mathrm{~m}$ (Table 2). Note that the contributions are added by adding their extremes, assuming the uncertainties are dependent (see also Section 2).

Severe scenario The modest scenario described above does not capture the idea of a collapse of the WAIS as imagined in several more severe depictions (Section 3.3, Mercer 1978; Vaughan 2008). We therefore developed a severe scenario based on emerging collapse of ASE and EAIS-g, and accelerating melting and glacier flow on in the n-AP as well.

During a collapse, the retreat of the ice and the contribution to sea level rise is not limited by the acceleration of the glaciers taking ice to the oceans, as suggested by the investigations of the upper bound of the AIS contribution to sea level rise by Pfeffer et al. (2008). For a marine ice sheet it is possible for the edge of the ice sheet to migrate inland, into increasingly deep ice, and this could cause a collapse of West Antarctic Ice Sheet at rates that are higher than could be achieved by glacier acceleration alone. It is generally thought that a full-scale collapse would be promoted by the removal of ice shelves that fringe the grounded ice sheet and act to buttress it. On the Antarctic Peninsula, loss of Larsen B Ice Shelf resulted in a speed-up of the glaciers that formerly fed it by factors of two to eight times (Scambos et al. 2004). If we imagine glacier acceleration at the upper end of this range we can come close to the rates of loss that could be described as a collapse. If the loss of ice from the glaciers across ASE increases to eight times the balance value, akin to what was observed after the loss of Larsen B ice shelf, it would result in an additional contribution of $3 \mathrm{~mm} / \mathrm{yr}$ to sea level rise. If this type of behavior followed an ice-shelf loss, it could, in theory dominate for much of the latter part of the century, giving a total contribution to sea level rise by 2100 on the order of $0.25 \mathrm{~m}$ (Table 2).

If the marine glacier basins in EAIS-g were to follow the progress of the ASE glaciers, effectively producing a 50\% excess in discharge over 30 years (from 2000), and then following exponential growth to 2100, this would imply around $0.19 \mathrm{~m}$ global mean sea level contribution in the period 2000-2100. In this severe scenario, the contribution from the n-AP glaciers is unlikely to be a significant fraction of the total. We note that the ice thickness on the n-AP (Pritchard and Vaughan 2007) is poorly surveyed, but is unlikely to contain more than $0.10 \mathrm{~m}$ global mean sea level equivalent. The potential contribution from this area is therefore unlikely to be substantially greater than $0.05 \mathrm{~m}$. For the purposes of this scenario, we assume that this $0.05 \mathrm{~m}$ is lost by 2100 . The total sea level contribution for the severe scenario due to changing ice dynamics is then $0.49 \mathrm{~m}$. To this estimate, we add again the global mean sea level change of $-0.08 \mathrm{~m}$ projected in response to an increase in accumulation (IPCC AR4), and arrive at an upper estimate of $0.41 \mathrm{~m}$. 
The modest and severe scenarios discussed above serve as the lower and higher end of the high-end projection for the contribution of the AIS to global mean sea level rise. It amounts to -0.01 to $0.41 \mathrm{~m}$ (Table 2, Fig. 1).

Pfeffer et al. (2008) estimated the AIS contribution at $0.13-0.15 \mathrm{~m}$ (low estimate) and $0.62 \mathrm{~m}$ (high estimate). The latter is considerably higher than ours, as a consequence of the entirely different starting-point that is chosen in the two studies. While Pfeffer et al. (2008) focus on kinematic constraints on the contribution by estimating an upper limit to the discharge of the glaciers, our approach focuses on the possible impacts of marine ice sheet instabilities. Based on their kinematic approach, Pfeffer et al. (2008) obtained their estimate for ASE (which is 0.05 to $0.15 \mathrm{~m}$ larger than ours) by setting an upper limit on the speed at which glaciers can transport ice to the sea. They assume a (not well-justified) increase in velocity to the highest value ever observed for an outlet glacier (Howat et al. 2007, an observation from Greenland), and maintain this for the remainder of the century. In contrast, we consider the consequences of a collapse of the ice sheet in response to the loss of the adjacent ice shelf by analogy with recent events at Larsen B ice shelf (Scambos et al. 2004). In our opinion, the latter scenario is more likely based on established vulnerability of the ASE Embayment to marine ice sheet instability (Vaughan 2008). Also as a consequence of the different approaches chosen, the two papers consider different regions in East Antarctica in their estimates. While Pfeffer et al. (2008) estimate a contribution for the largest outlet glacier (the Amery/Lambert drainage basin, Rignot et al. 2008), we estimate the contributions from the marine-based glaciers prone to marine ice sheet instability (Pritchard et al. 2009). Finally, part of the difference between the two estimates can be explained by the fact that Pfeffer et al. (2008) only consider SMB changes on the Antarctic Peninsula (assessed at $+0.01 \mathrm{~m}$ ) while we take into account the projected accumulation changes over the entire continent (assessed at $-0.08 \mathrm{~m}$ ). The two estimates for the dynamic contribution from the Antarctic Peninsula hardly differ.

\subsubsection{Greenland Ice Sheet (GIS)}

For Greenland, recent studies indicate a larger ice mass loss than at the time that IPCC AR4 was published (Fig. 3, see also Allison et al. 2009). Also for the high-end scenario for GIS, we accept the IPCC AR4 assessment of mass loss due to surface mass balance changes and associated sea level rise, and reassess only the additional contribution from fast dynamical processes.

The first process that may be important for enhanced dynamical discharge from GIS is related to percolation of the melt water to the bedrock, either directly from surface melt or lake drainage. At the bedrock the additional water might lubricate the ice and increase the flow of ice to lower lying areas. This process, known to be important for Alpine glaciers, was first noticed to be significant at GIS by Zwally et al. (2002). More recently satellite interferometry data (Joughin et al. 2008a) confirmed that the velocity accelerations in summer are widespread along the western margin. Based on GPS measurements along the K-transect $(67 \mathrm{~N})$ it was shown (van de Wal et al. 2008) that accelerations of up to $300-400 \%$ occur during short intervals, but no long-term increase in the velocity could be observed whereas the ablation increased slightly over the last 17 years (see also Katsman et al. 2008a, Section 5.4.2). Quantification of the feedback mechanisms related to lubrication of the bed is part of ongoing research. 


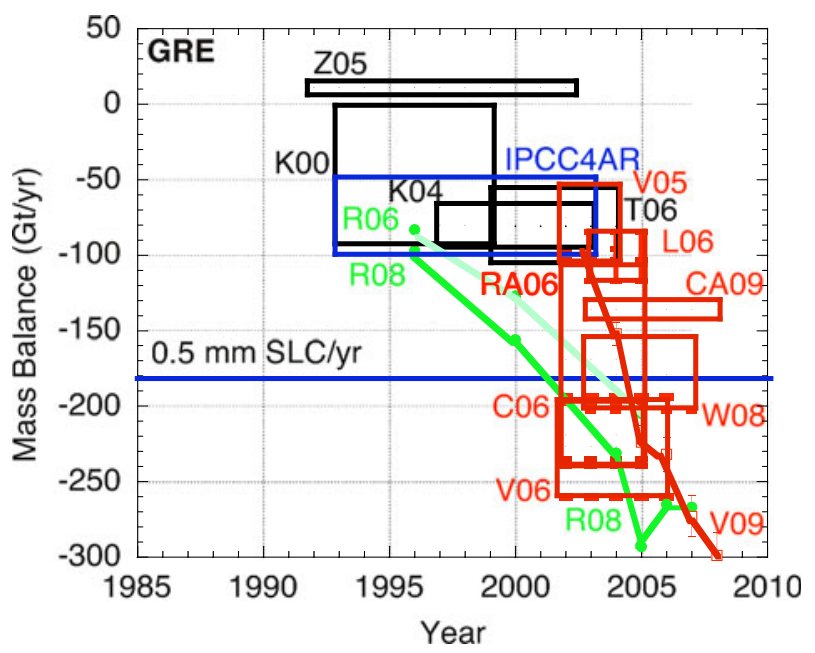

Fig. 3 Various estimates of the mass balance of the Greenland Ice Sheet (GIS), inferred from green-Insar measurements of ice velocity; red-gravitational measurements (GRACE); blackradar altimetry [C06: Chen et al. 2006; CA09: Cazenave et al. 2009; K00: Krabill et al. 2000; K04: Krabill et al. 2004; L06: Luthcke et al. 2006; R06: Rignot and Kanagaratnam 2006; R08: Rignot et al. 2008; T06: Thomas et al. 2006; RA06: Ramillien et al. 2006; V05: Velicogna and Wahr 2005; V06: Velicogna and Wahr 2006b; V09: Velicogna 2009; W08: Wouters et al. 2008; Z05: Zwally et al. 2005]. The IPCC estimate for GIS (blue box) is based on Z05, K00, V05, R06 and C06

As in West Antarctica, there are regions of GIS where a retreating ice shelf can lead to a retreat of the ice at a rapid rate that depends on basal melt rates (e.g., Pfeffer 2007). This process depends on ocean water temperatures. A complicating factor in quantifying this process for Greenland lies in the fact that the inlets which are at present below sea level are typically narrower than comparable areas in Antarctica. This is particularly true for the Jakobshavn basin. This basin captures an amount of ice that, if mobilized rapidly, would lead to a sea level rise of approximately $0.35 \mathrm{~m}$. At present there is insufficient knowledge to quantify the effect of the narrow inlets and their consequences for the drainage of ice to the ocean. Some data are available on the acceleration of tidewater glaciers, which can be used to estimate the fast dynamical discharge (Joughin et al. 2004; Howat et al. 2007; Joughin et al. 2008 b). For the tide water glaciers in the east and south we assume a doubling of the discharge by 2050 compared to its 1996 value $\left(21 \%\right.$ of $386 \mathrm{~km}^{3} / \mathrm{yr}$, Rignot and Kanagaratnam 2006), followed by rapid slow down to 1996 discharge rates when their termini no longer reach the ocean. Jakobshavn and the northern tidewater glaciers are assumed to be at four times their 1996 discharge rates $\left(18 \%\right.$ of $386 \mathrm{~km}^{3} / \mathrm{yr}$, Rignot and Kanagaratnam 2006) by 2100 , which is an acceleration comparable to observations in West-Antarctica. (All changes in the rates are assumed linear.) The resulting analysis yields an additional sea level rise by 2100 due to fast ice dynamics of about $0.10 \mathrm{~m}$ on top of the estimate from the surface mass balance of 0.03 to $0.12 \mathrm{~m}$, which is calculated based on the considered range in atmospheric temperature rise and the surface mass balance sensitivity presented in IPCC AR4 
(Katsman et al. 2008a, p. 57). The total high-end contribution of GIS to global mean sea level rise is assessed at 0.13 to $0.22 \mathrm{~m}$.

Our estimate of the dynamical contribution of $0.1 \mathrm{~m}$ is roughly consistent with the upper end of the IPCC AR4 suggestion of scaled-up ice discharge due to fast dynamics of $0.17 \mathrm{~m}$ for the A1FI scenario from both ice sheets, if the IPCC contribution can be distributed equally over GIS and AIS. A linear extrapolation of the observations in Fig. 3 also leads to a contribution from GIS of about 0.2 $\mathrm{m}$ in 2100. The low scenario of Pfeffer et al. (2008) is an independent estimate based on similar kinematic considerations and yields $0.17 \mathrm{~m}$ as well. Also for GIS, our estimate is considerably smaller than the high scenario in Pfeffer et al. (2008) $(0.54 \mathrm{~m})$, which assumes a rapidly accelerating dynamic discharge from the outlet glaciers until a maximum rate, which is then maintained until 2100. However, as argued in Section 3.2, it is likely that several tidewater glaciers will retreat above sea level over time, yielding a consequent reduction in discharge. Moreover, the maximum rate is assumed to be an order of magnitude larger than the current discharge rate of the outlet glaciers. Such an increase has never been observed, nor is the reason for choosing this ten-fold increase motivated in the paper.

\subsection{Total}

To arrive at a projection for total mean sea level rise, we sum the median values of the individual components and sum their uncertainties quadratically (see Section 1). The final range is rounded off to the nearest $0.05 \mathrm{~m}$. For 2100 , we arrive at a plausible high-end scenario for global mean sea level rise of 0.55 to $1.15 \mathrm{~m}$.

Not surprisingly, this high-end estimate lies above the IPCC projections, which represent a likely range and incorporate only a limited range of possible ice sheet responses, as they do not include potential contributions resulting from rapid dynamical processes in GIS and AIS. For the A1FI emission scenario, a global mean sea level rise of $0.26-0.59 \mathrm{~m}$ in 2100 with respect to 1990 was projected. When the contribution referred to as the scaled-up ice discharge (Section 10.6.5 in IPCC AR4) is included, the projected range becomes $0.25-0.76 \mathrm{~m}$.

The high-end estimate presented here is lower than the outcomes of several semiempirical model studies (e.g., Rahmstorf 2007a; Grinsted et al. 2009; Vermeer and Rahmstorf 2009; Jevrejeva et al. 2010). However, it should be noted that the semiempirical approach in its original formulation (Rahmstorf 2007a) has been contested on statistical and on physical grounds (Schmith et al. 2007; Holgate et al. 2007; von Storch et al. 2009; Rahmstorf 2007b). The linear scaling relation is a simple firstorder approximation to a number of complex processes influencing sea level change. The argument given by Rahmstorf (2007a) to justify its use is that our capability for calculating future sea-level changes with present physics-based models is very limited, and that these semi-empirical models can provide a pragmatic alternative to estimate the sea-level response. However, when applied to the results of climate model simulations, the semi-empirical formula from Rahmstorf (2007a) appears to overpredict sea level rise due to thermal expansion in 2100 by $20-30 \%$ in comparison to the actual modeled expansion (see Rahmstorf 2007a, Fig. S3 and Katsman et al. 2008a, p. 40-44). Although apparently this problem of overestimation can be fixed by 
using an expanded version of the approach (Vermeer and Rahmstorf 2009), clearly more research is needed to determine the skill of the (various formulations of the) semi-empirical approach before the value of the resulting projections for sea level rise can be properly assessed.

\section{Local sea level rise in 2100}

To develop a local high-end scenario for the Netherlands, we account for two local effects (see Section 2): local steric changes with respect to the the global mean change, and elasto-gravity effects.

Local steric changes Regionally, changes in steric sea level (caused by changes in temperature and salinity) can deviate substantially from the global mean value. Katsman et al. (2008b) analyzed modeled steric changes in the northeast Atlantic Ocean for the twenty-first century as a function of atmospheric temperature rise. From the analysis, two types of model behavior emerge. Either the local changes are the same as the global mean changes, or an additional local rise is seen which increases with rising atmospheric temperatures. The latter behavior reflects a dynamical sea level change associated with a reduction of the strength of the meridional overturning circulation that occurs in those model simulations (Levermann et al. 2004). The high-end contribution of additional sea level rise due to ocean circulation changes in the North East Atlantic Ocean is defined using the relation found in Katsman et al. (2008b) applied to the rise in global mean temperature considered here. Its (skewed) contribution is assessed at -0.05 to $0.20 \mathrm{~m}$ (Katsman et al. 2008a, p. 27).

Elasto-gravity effects Besides local sea level variations due to ocean circulation changes, we take into account that when ice masses on land melt, the resulting melt water is not distributed evenly over the oceans. Large land-based ice masses exert a gravitational pull on the surrounding ocean, yielding higher relative sea levels in the vicinity of the ice mass. When the ice mass shrinks, this pull decreases, and sea level will actually drop in the vicinity of the ice sheet (the "near field") as water is redistributed away from it (Woodward 1888; Farrell and Clark 1976). Farther away from the land ice mass, in the "intermediate field", sea level does rise, but this rise is smaller than the global mean rise that would result from equal distribution of the melt water. At even greater distances, in the "far field", local sea level rise becomes larger than the global mean rise. Moreover, the solid Earth deforms under the shifting loads. This deformation affects the gravity field, the distribution of the ocean water, and the vertical position of land. As a result of these local gravitational and elastic changes, along with accompanying changes in the orientation of Earth's rotation axis and the rate of rotation, a shrinking land ice mass yields a distinct pattern of local sea level rise sometimes referred to as its "fingerprint" (e.g., Mitrovica et al. 2001; Plag and Juettner 2001). The gravitational, elastic and rotational effects can be incorporated in the scenario for sea level rise by multiplying each of the global mean contributions from ice melt from glaciers and ice sheets by their respective relative fingerprint ratios.

Two approaches can be used to quantify the effect for small glaciers, which are distributed unevenly over the world. The first one is to use the data set on increase 
in sea level due to glacier melt by Dyurgerov and Meier (2005) covering the period from 1961-2003. From this data set, we can reconstruct sea level due to glacier melt for different regions over the last four decades. Taking the geographical location of the areas relative to the Netherlands, as a first approximation we can simply calculate the local sea level rise due to gravitational effects caused by the different small glacier areas (for a rigid Earth). This exercise results in a ratio of local to global mean sea level for the Netherlands that varies over time depending on which areas are important, but ranges from 0.75 to 0.90 . It is smaller than unity due to the contribution of a few glaciers close to the Netherlands, such as those on Iceland and Svalbard. This analysis applies to the past sea level contribution by small glaciers, but the local effect for future sea level rise may be different. In order to assess this point, we can use the estimated regional distribution of glacier melt under $2 x \mathrm{CO}_{2}$ conditions presented by van de Wal and Wild (2001). This results in a ratio of 0.8 for the local/global mean ratio. This number coincidently agrees with the one presented by Mitrovica et al. (2001), which is based on a model of gravitational and elastic effects resulting from historical glacial melting between 1900 and 1961. In all, we used a scaling factor of 0.8 for the glacier contribution along the Dutch coast based on the above analysis.

Simple calculations for a rigid Earth yield a fingerprint ratio of 0.45 and 1.2 for for GIS and AIS, respectively (Woodward 1888). However, there appear to be large differences in the fingerprints published by various authors who have addressed the impacts of the deformation of the Earth's crust in response to mass load changes for these ice sheets. In particular, Plag and Juettner (2001) predict fingerprints with much larger spatial variability than, e.g., Mitrovica et al. (2001); Farrell and Clark (1976) and Clark and Primus (1988). The reasons for these discrepancies are not fully understood. In order to assess the impact of the current uncertainty in the fingerprints of AIS and GIS on the local sea level projections, we have considered the two widely varying cases published by Mitrovica et al. (2001) and Plag and Juettner (2001) (solid and open bars in Fig. 1, Table 1). We arrive at a high-end scenario for sea level rise along the coast of the Netherlands of 0.40 to $1.05 \mathrm{~m}$ using the fingerprints published by Mitrovica et al. (2001). In contrast, using the results by Plag and Juettner (2001) yields a high-end scenario of -0.05 to $1.15 \mathrm{~m}$.

\section{High-end scenario for 2200}

A long-term, high-end scenario for local sea level rise for the year 2200 can be very useful for those involved in coastal management, but developing it is a challenging task. Robust sea level rise projections are not yet possible since scientific understanding of some processes is incomplete, and hence not well-captured by models. Moreover, for the period 2000-2100, at least the initial condition is reasonably constrained, and the same is not true for the period 2100-2200. As a consequence, the high-end scenario presented here is a rather crude estimate. It is unlikely that the amount of sea level rise that is attained by 2200 will be less than twice the lower limit projected for $2100(1.1 \mathrm{~m})$, because we expect the temperature forcing to be large throughout the twenty-second century, and both the thermosteric and ice sheets components have very long response time scales. 


\subsection{Global mean scenario}

For 2200, estimates of the global mean thermal expansion can be obtained by either considering the limited set of climate model simulations that cover (part of) the twenty-second century (Meehl et al. 2007b), or by applying an extrapolation method like the semi-empirical approach (Rahmstorf 2007a) to twenty-first century model results. The long-term climate model simulations that are available for the twentysecond century are those that assume a stabilization of the $\mathrm{CO}_{2}$ concentration in 2000 (Wigley 2005) or in 2100 (SRES A1B, Fig. 10.37 in IPCC AR4), or those that assume a $1 \%$ per year increase in $\mathrm{CO}_{2}$ until a quadrupling of pre-industrial values is obtained (simulations end in the year 2140, see Fig 11.15 in IPCC AR4 and Houghton et al. 2001). On average, these model simulations yield a contribution of $0.4-1.0 \mathrm{~m}$ from global mean thermal expansion in 2200 with respect to 1990 (Katsman et al. 2008a, p. 44). However, the associated rise in global mean atmospheric temperature projected in these simulations is only about $3-4 K$, which is considerably smaller than the range of $\Delta T_{\mathrm{atm}}=2.5-8 \mathrm{~K}$ assumed here (Section 2). As a consequence, the estimate for global mean thermal expansion in 2200 obtained from these longterm climate model simulations is probably too low as well.

Therefore, we choose the second option and estimate the global mean thermal expansion by applying the semi-empirical approach (Rahmstorf 2007a) to a suite of twenty-first century climate model results (Katsman et al. 2008a, Section 3.1), despite the fact that application of this approach has its limitations (Section 3.4). These limitations particularly apply when the semi-empirical relation between sea level rise and atmospheric temperature that is used is derived based on twentieth century observations. For this period, it may be hard to distinguish between a climatechange related signal and natural variability. Here, we define the semi-empirical relation based on the results of a suite of climate model simulations for the twentyfirst century (Katsman et al. 2008a, Section 5.3.1). For this period, the ratio of the climate-change related signal to the natural variations is more favorable, which can be expected to improve the skill of the projection. Nonetheless, the results need to be treated with caution. For $\Delta T_{\mathrm{atm}}=2.5-8 \mathrm{~K}$ in 2200 (Lenton 2006), the analysis yields a central estimate of $0.8 \mathrm{~m}$ for the global mean thermal expansion, with a skewed distribution ranging from 0.3 to $1.8 \mathrm{~m}$ (Fig. 4, Table 3 ).

Fig. 4 Individual contributions and total high-end projections for 2200 (red: global mean sea level rise; blue: local sea level rise along the Dutch coast using the fingerprint ratios presented by (solid bars) Mitrovica et al. (2001) and (open bars) Plag and Juettner (2001), respectively)

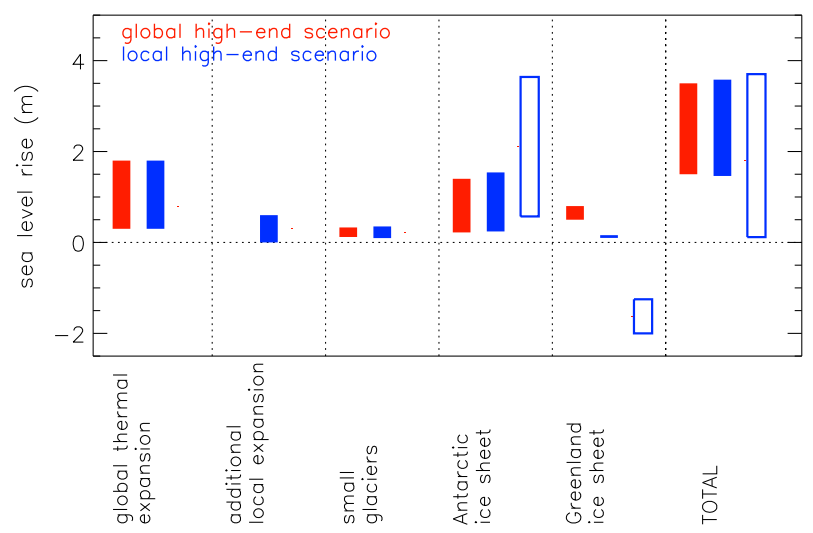


Table 3 Overview of all estimated contributions and the total high-end projections for 2200 assessed here and displayed in Fig. 4 (in $\mathrm{m}$ ), for global mean sea level rise and for local sea level rise along the Dutch coast using two different scaling factors used to translate the global mean contributions from land ice masses to local variations (left: Mitrovica et al. (2001), right: Plag and Juettner (2001); see Section 4 for details)

\begin{tabular}{lllc}
\hline & Global high-end & \multicolumn{2}{l}{ Along the Dutch coast, high-end } \\
\hline Global mean expansion & $0.3-1.8$ & $0.3-1.8$ & $0.3-1.8$ \\
Local expansion & - & $0.0-0.6$ & $0.0-0.6$ \\
Small glaciers & $0.12-0.44$ & $0.10-0.26$ & $0.10-0.26$ \\
Antarctic ice sheet & $0.22-1.4$ & $0.24-1.5$ & $0.57-3.6$ \\
Greenland ice sheet & $0.5-0.8$ & $0.10-0.16$ & $-1.25--2.0$ \\
Total & $1.5-3.5$ & $1.5-3.5$ & $0.0-3.5$ \\
\hline
\end{tabular}

Final numbers are rounded off to $0.5 \mathrm{~m}$

As an estimate for the contribution of glaciers, we again apply the scaling relation discussed in IPCC AR4 (see Section 3.2 for details). Using a global glacier volume ranging from 0.15 to $0.60 \mathrm{~m}$ (Ohmura 2004; Dyurgerov and Meier 2005; Raper and Braithwaite 2005; Radic and Hock 2010) yields a global mean contribution of 0.12 to $0.44 \mathrm{~m}$ between 2000 and 2200 (Fig. 4, Table 3), more than twice the amount assessed for 2100 (Fig. 1, Table 1).

A key uncertainty for long-term projections of sea level rise is the potential rate at which GIS and AIS can contribute to sea level rise over the coming centuries. We base a conservative projection of the contribution of ASE to sea level rise by 2200 on a simple continuation (no further acceleration) of the low discharge rate achieved at 2100 (Section 3.3.1). This would produce about $0.22 \mathrm{~m}$ of sea level rise by 2200 (Fig. 4, Table 3). It is clear that if such a rate of discharge is attained by 2100 , it is unlikely to be reduced thereafter and so this can provide a justifiable lower limit. Similarly, continuing the rate of contribution from the upper estimate of the higher scenario would suggest a total contribution by 2200 approaching $1.4 \mathrm{~m}$ global mean sea level rise. Given the uncertainty in these numbers, we omit here the small correction estimated to arise from additional accumulation (see also p. 32 in Katsman et al. 2008a). For GIS, based on the same assumptions as formulated for 2100 (p. 33 in Katsman et al. 2008a), the additional sea level rise due to fast ice dynamics is estimated at $0.3 \mathrm{~m}$, which amounts to a complete disappearance of the Jakobshavn Isbrae drainage basin. A further decrease of the surface mass balance by another 0.05 $\mathrm{m}$ for the moderate scenario and $0.3 \mathrm{~m}$ for the high scenario seems possible given the projections for the twenty-first century, adding up to a total GIS contribution to sea level rise by 2200 of 0.5 to $0.8 \mathrm{~m}$ (Fig. 4, Table 3 ).

The sum of the contributions yields a crude estimate for global mean sea level rise in 2200 of 1.5 to $3.5 \mathrm{~m}$ (rounded off to the nearest $0.5 \mathrm{~m}$ because of the large uncertainties).

\subsection{Local scenario for the Netherlands}

A high-end scenario for sea level rise for the Netherlands for the twenty-second century needs to account for the possibility of a shutdown of the thermohaline circulation and the associated additional local expansion of about $0.6 \mathrm{~m}$ in the North Atlantic Ocean (Levermann et al. 2004; Yin et al. 2009). However, it is at present 
impossible to assign any likelihood to such a scenario, and the other extreme, an unchanged thermohaline circulation, cannot be ruled out either. The additional local expansion is therefore estimated at 0.0 to $0.6 \mathrm{~m}$ in 2200 with respect to 2000 (Fig. 4, Table 3).

Second, the global mean contributions from land-based ice masses are again translated to local values to take into account the elastic and gravitational effects. Using the numbers from Mitrovica et al. (2001), the scenario for local sea level rise for the Netherlands yields 1.5 to $3.5 \mathrm{~m}$ (0.0 to $3.5 \mathrm{~m}$ using Plag and Juettner (2001), Fig. 4, Table 3).

\section{Paleoclimatic evidence of global mean sea level rise}

During the Last Interglacial stage, about 120-130 thousand years ago, global temperatures were comparable to or modestly warmer than their pre-industrial levels, while polar temperatures were about $3-5 K$ warmer than today, an amount of warming similar to that expected to accompany about $1-2 K$ of global warming (e.g., Overpeck et al. 2006; Otto-Bliesner et al. 2006; Duplessy et al. 2007; Jansen et al. 2007; Kopp et al. 2009; Clark and Huybers 2009). Statistical analysis of a global database of sea level indicators indicates that it is extremely likely that global sea level peaked at least $6.6 \mathrm{~m}$ higher than today during that period. It also finds that, during the interval within the Last Interglacial when global sea level exceeded -10 $\mathrm{m}$ and ice sheets of the scale of the present GIS and WAIS were therefore the only major meltwater contributors, millennial-average rates of global sea level rise exceeded $5.6 \mathrm{~m} / \mathrm{ky}$ (Kopp et al. 2009). Examination of individual quasi-continuous paleo-sea level records, including a global sea level record derived from oxygen isotopes (Lisiecki and Raymo 2005) and a local sea level record of the Red Sea (Rohling et al. 2008), suggests that rates of sea level rise reached 0.7 to $1.7 \mathrm{~m} /$ century during this interval (Table 4, Fig. 5). Such records are not, however, of high enough temporal resolution to exclude the possibility that global sea level rose at faster rates for periods of less than about three centuries, nor can they provide a minimum constraint on how long it takes to attain such rates starting from a slow rate of sea level rise comparable to that we are experiencing now. The variations in the rate of local sea level rise observed in the Red Sea record (Rohling et al. 2008) do, however, suggest that the onset of rapid sea level rise can occur within the $\sim 300$ year timescale resolved by that record. A plausible high-end estimate based

Table 4 Paleoclimatic estimates of rates of sea level rise (error bars are $2 \sigma$ estimates)

\begin{tabular}{lllcrll}
\hline Data set & $\begin{array}{l}\text { Time } \\
(\mathrm{ka})\end{array}$ & $\begin{array}{l}\text { Rate } \\
(\mathrm{m} / \mathrm{cty})\end{array}$ & Sea level from & $\begin{array}{l}\text { Rise } \\
(\mathrm{m}) \text { to }\end{array}$ & $\begin{array}{l}\text { Duration } \\
(\mathrm{ka})\end{array}$ & $\begin{array}{l}\text { Sampling } \\
\text { interval }\end{array}$ \\
\hline LR05 & $127-126$ & $1.3 \pm 1.0$ & $-8.4 \pm 8.2$ & $4.2 \pm 6.6$ & $1.0 \pm 0.5$ & $\sim 1 \mathrm{kyr}$ \\
& $124-123$ & $1.0 \pm 0.9$ & $-2.4 \pm 6.1$ & $7.8 \pm 8.0$ & $1.0 \pm 0.5$ & $\sim 1 \mathrm{kyr}$ \\
S00 & $127-126$ & $1.2 \pm 0.7$ & $1.1 \pm 5.5$ & $13.8 \pm 5.5$ & $1.1 \pm 0.5$ & $\sim 300 \mathrm{yr}$ \\
R08 & $126-125$ & $1.6 \pm 1.1$ & $-5.2 \pm 6.0$ & $5.2 \pm 6.4$ & $0.6 \pm 0.2$ & $\sim 300 \mathrm{yr}$ \\
& $124-123$ & $1.5 \pm 1.4$ & $4.7 \pm 6.4$ & $11.6 \pm 6.0$ & $0.5 \pm 0.1$ & $\sim 450 \mathrm{yr}$ \\
Z83 & $128-126$ & $0.9 \pm 0.6$ & $-6.3 \pm 3.8$ & $4.4 \pm 2.8$ & $1.3 \pm 0.6$ & $\sim 1.3 \mathrm{kyr}$ \\
\hline
\end{tabular}

Listed data sets are LR05: Lisiecki and Raymo 2005; S00: Shackleton et al. 2000; R08: Rohling et al. 2008; Z83: Zagwijn 1983 
a

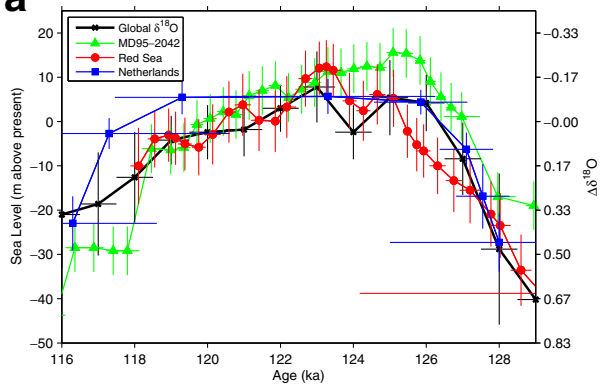

b

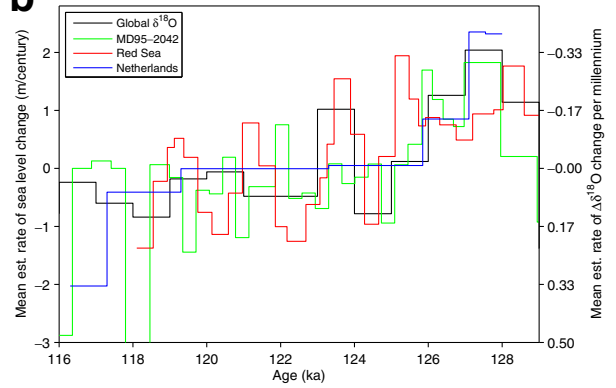

Fig. 5 a Last Interglacial local sea level records from the Red Sea (Rohling et al. 2008) and the Netherlands (Zagwijn 1983) compared to global sea level records derived from the global benthic foraminifera oxygen isotope curve (Lisiecki and Raymo 2005) and the high resolution benthic foraminifera oxygen isotope curve from Iberian core MD95-2042 (Shackleton et al. 2000). The Red Sea curve is from core KL-11 (Rohling et al. 2008) smoothed with a 1000-year Gaussian filter, and with an age model scaled and shifted so as to align with the global oxygen isotope curve. The Dutch data (Zagwijn 1983) has been adjusted for long-term isostatic subsidence, tectonic subsidence, and compaction using backstripping-derived Quaternary rate estimates (Kooi et al. 1998). Its age model is based on the duration of Eemian pollen zones (Zagwijn 1996) placed in time so that the record aligns with the global oxygen isotope curve. Further details on the interpretation of the Red Sea and Dutch records are provided in the Supplementary Material to Kopp et al. (2009). Sea level records were derived from the benthic oxygen isotope curves by linear scaling to $125 \mathrm{~m}$ of sea level change from the present to the Last Glacial Maximum. The deviations of oxygen isotopes from modern values are shown on the right $y$-axis. The MD95-2042 (Shackleton et al. 2000) curve has been smoothed with a 700- year Gaussian filter, and its age model has been slightly adjusted (by $<1,500 \mathrm{yrs}$ ) from that of to align with the global oxygen isotope curve. Vertical error bars denote $2 \sigma$ intervals; $\mathbf{b}$ Mean rate of sea level rise estimated from the sea level records displayed in a

on paleoclimate evidence, assuming that rates of global mean sea level rise as fast as $\sim 1.7 \mathrm{~m} /$ century can commence on a decadal timescale, yields a global mean sea level rise of roughly $1.4 \mathrm{~m}$ in 2100 . This is somewhat higher than the high-end projection of up to $1.15 \mathrm{~m}$ presented in Section 3.4, indicating that the latter estimate is not infeasible. An alternative geochronology for the Last Interglacial, preferred by some authors (e.g. Rohling et al. 2008), shortens the duration of the stage and would suggest rates of sea level reached 1.0 to $2.4 \mathrm{~m} /$ century. An estimate for 2100 based on the higher value of $\sim 2.4 \mathrm{~m} /$ century would yield a sea level of roughly $1.9 \mathrm{~m}$ in 2100 .

\section{Implications for flood protection of the Netherlands}

For the Netherlands, sea level rise is not the only possible threat resulting from climate change. Possible changes in storm surges and increased river discharge also need to be considered in the country's flood protection strategy. Sterl et al. (2009) assessed extreme surge heights at the Dutch coast for two 51-year periods (19502000 and 2050-2100), using the wind fields from a 17-member ensemble climate change simulation (Sterl et al 2008a) in combination with an operationally-used surge model for the North Sea area. Wind speeds in the southern North Sea are projected to increase (Fig. 6a) due to an increase in south-westerly winds (Sterl et al 2008b). However, the highest surges along the Dutch coast are caused by northwesterlies because of their long fetch and the geometry of the coastline. As a result, local 
a

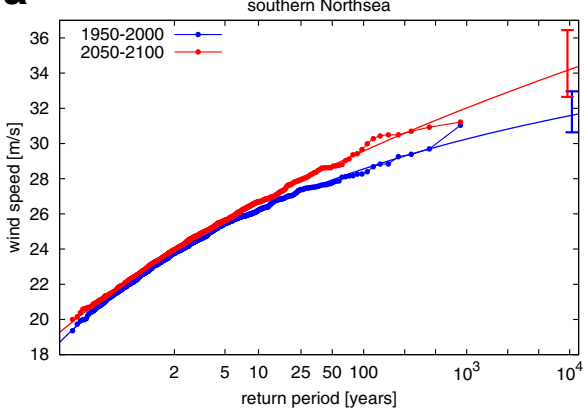

b

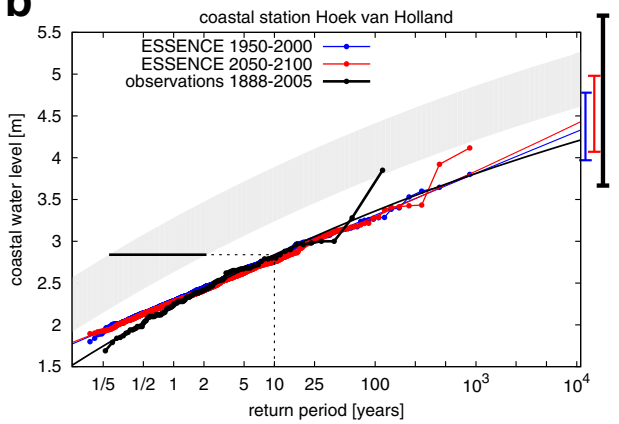

Fig. 6 Present (blue, 1950-2000) and future (red, 2050-2100) wind speed in the southern North Sea $\mathbf{a}$ and water level at coastal station Hoek van Holland $\mathbf{b}$, as a function of the return period. In $\mathbf{b}$, also the observed values for the period 1888-2005 are shown (black). The bars at the right margin denote the $95 \%$ confidence intervals of the fit for a return period of 10,000 years. The wind data are from an ensemble of climate model simulations (Sterl et al 2008a), and the water levels from a storm surge model for the North Sea driven by these winds. In $\mathbf{b}$, the combined impacts of local sea level rise and storm surges are illustrated by considering the criterion for the closing of the storm surge barrier that protects Rotterdam harbor (see main text for details)

extreme surge heights are largely unaffected by the increase in wind speed (Fig. 6b, Sterl et al. 2009), as was found in earlier climate model studies (WASA-Group 1998; Woth 2005; Lowe and Gregory 2005).

The Netherlands also faces possible flooding from the river Rhine (Fig. 7) as the peak discharge of the river Rhine is estimated to increase. In the eastern part of the Dutch delta, the levees along the river are designed to withstand a flood with a 1250 years return period. Currently this is associated with a peak discharge of $16 \cdot 10^{3} \mathrm{~m}^{3} / \mathrm{s}$. Studies using climate models in combination with hydrological models indicate that the peak discharge may increase by about 5 to $40 \%$ to as much as $22 \cdot 10^{3} \mathrm{~m}^{3} / \mathrm{s}$ over the twenty-first century (dashed blue bar, lower right inset of in Fig. 7), mostly due to an increase in mean winter precipitation combined with a shift from snowfall to rainfall in the Alps (e.g., Middelkoop et al. 2001; Shabalova et al. 2004; Lenderink et al. 2007). Besides the physical aspects, future changes in peak discharge in the Netherlands may also be affected strongly by (future) flood defense measures taken upstream. Flood defense guidelines in Germany are currently less strict than in the Netherlands, and probably will remain so in the near future. As a consequence, uncontrolled upstream flooding is anticipated in case of extreme discharges, preventing these extreme discharges from reaching the Dutch part of the Rhine delta. Taking this constraint into account, the peak river discharge for the Netherlands for 2100 is estimated to increase only by about $10 \%$ to $17.5 \cdot 10^{3} \mathrm{~m}^{3} / \mathrm{s}$ rather than by up to $40 \%$ (solid blue bar in Fig. 7; Beersma et al. 2008, p. 136-137).

The combined effects of sea level rise, possible changes in storm surge height, and increased river discharge impose a complex flood risk that becomes apparent when considering the situation at one of the largest harbors in the world: Rotterdam (Fig. 7). The harbor is protected by a storm surge barrier, which is programmed to close automatically when the local water level reaches a prescribed criterion (nearly $3 \mathrm{~m}$ above normal conditions). Nowadays, the criterion corresponds to an economically acceptable closing frequency of about once every 10 years (black 


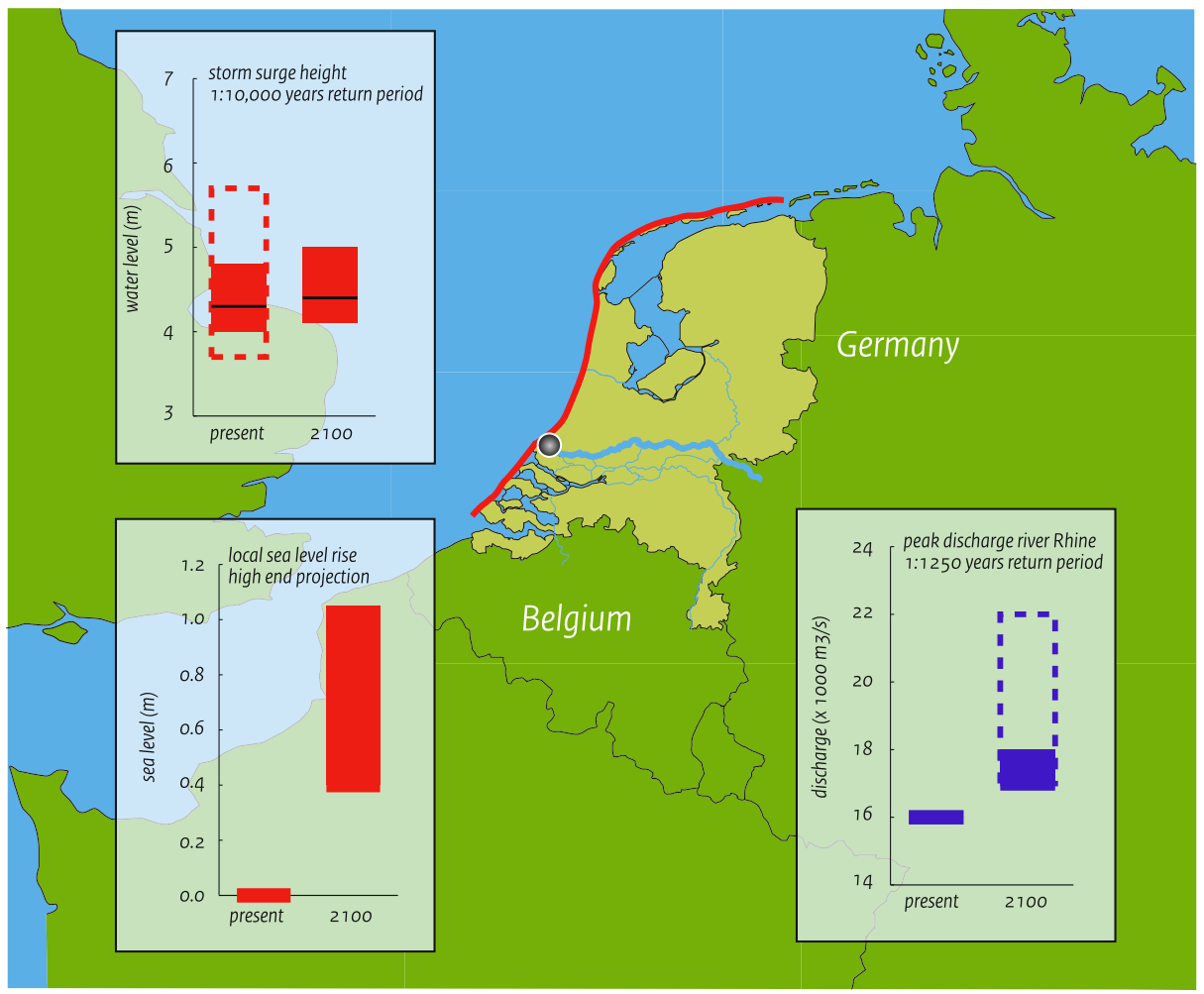

Fig. 7 Map of the Netherlands illustrating the combined threats of local sea level rise, possible changes in storm surges, and increased discharge of the river Rhine resulting from climate change on the country's flood defense system along the coast (red) and along the river Rhine (light blue). The location of the port of Rotterdam is marked by a black circle. Besides the high-end scenario for local sea level rise discussed in this paper (inset on the lower left), it also summarizes the high-end climate change scenarios for storm surge height (upper left, Sterl et al 2008b) and peak discharge of the river Rhine (lower right, Beersma et al. 2008) for 2100. For the storm surge height (upper left), a best estimate (black line) and $95 \%$ confidence interval (red bar) are given based on Fig. $6 \mathrm{~b}$. No significant change in extreme storm surge heights is anticipated. Note the narrowing of the confidence interval obtained by analyzing an ensemble of model simulations (solid bar) rather than observations (dashed bar) for the present-day conditions. The peak discharge of the river Rhine is projected to rise significantly due to precipitation changes over its catchment area (dashed blue bar). However, it is anticipated that uncontrolled flooding upstream, in Germany, will strongly reduce extreme discharge peaks before they reach the Netherlands (solid blue bar)

dotted line in Fig. 6b). The impacts of local sea level rise on this closing frequency can be illustrated by simply adding the projected sea level rise to the surge height (gray band in Fig. 6b), since, to first order, the characteristics of the latter do not change with the increase in water depth (Lowe and Gregory 2005). As indicated by the horizontal black line in Fig. 6b, the local water level is expected to reach the closure criterion five to fifty times more often than at present if that scenario for local sea level rise becomes reality.

In addition, the projected increases in sea level and peak river discharge will significantly enhance the probability that closure of the storm surge barrier is required while the river discharge is large. During closure, the river system behind 
the barrier rapidly fills, increasing the local flood risk. Further research is needed to quantify this increased risk in its full complexity. It depends among others on the duration of the closure (which in turn depends on the duration of the storm and the timing with the tidal phase) and on the (future) temporal storage or re-routing of the river discharge through the interacting distributaries in the lower Rhine-Meuse delta under extreme river discharge conditions.

The high-end scenarios for local sea level rise presented here form the basis for updated flood protection strategies for the Netherlands (Deltacommissie 2008; Kabat et al. 2009). Comprehensive monitoring is essential to be able to further narrow the uncertainties and re-evaluate flood management practices when necessary. Also, the discrepancy in the quantification of the gravity-elastic effects apparent in the published elastic fingerprints needs to be resolved in order to develop reliable scenarios for local sea level rise. Although they will also be affected by local oceanatmosphere dynamics, comprehensive observations of vertical land motion and sea level close to rapidly changing large ice masses can serve as a basis for validating the published elastic fingerprints. Such observations are only starting to become available (e.g., Khan et al. 2007). A factor that influences local sea level that is not accounted for in this local scenario is the response of the ocean circulation to land ice changes through melt water run-off. However, the current generation of coupled climate models does not contain an interactive land ice module (melt water from land ice is not added to the ocean; modeled ocean salinity changes are due to changes in sea ice conditions, evaporation minus precipitation and river runoff only). Hence, this effect cannot be included in our local projection because of lack of proper numerical simulations. From dedicated numerical simulations (so-called hosing experiments), we know that the local freshening can have a substantial impact on the ocean circulation (e.g., Vellinga and Wood 2002; Laurian and Drijfhout 2010), with consequent effects on local sea level (Stammer 2008). However, the amount of melt water added to the ocean in these simulations is much larger than current observations of ice sheet mass loss suggest appropriate. In the near future, we expect the climate models to improve with regard to this aspect so that it will be possible to incorporate this ocean-ice interaction effect in local projections.

Acknowledgements The authors acknowledge the members of the Dutch Delta Committee, and in particular Pavel Kabat, for initiating this research. J.A.C. was partly funded by the Australian Climate Change Science Program and the Pacific Climate Change Science Program, which is supported by AusAID, in collaboration with the Department of Climate Change and Energy Efficiency. R.E.K. was supported by a postdoctoral fellowship in the Science, Technology, and Environmental Policy program at the Woodrow Wilson School at Princeton University.

Open Access This article is distributed under the terms of the Creative Commons Attribution Noncommercial License which permits any noncommercial use, distribution, and reproduction in any medium, provided the original author(s) and source are credited.

\section{References}

Alley RB, Fahnestock M, Joughin I (2008) Understanding glacier flow in changing times. Science 322:1061-1062

Allison I, Alley RB, Fricker HA, Thomas RH, Warner R (2009) Ice sheet mass balance and sea level. Antarct Sci 21. doi:10.1017/S0954102009990,137 
Antonov JI, Levitus S, Boyer TP (2002) Steric sea level variations 1957-1994: importance of salinity. J Geophys Res 107. doi:10.1029/2001JC000,964

Bamber JL, Riva REM, Vermeersen BLA, LeBrocq AM (2009) Reassessment of the potential sea-level rise from a collapse of the West Antarctic ice sheet. Science 324:901-903. doi:10.1126/science.1169335

Beersma JJ, Kwadijk J, Lammersen R (2008) River Rhine discharge. In: Exploring high-end climate change scenarios for flood protection of the Netherlands. KNMI/Alterra, The Netherlands, pp 99-142. Available from http://www.knmi.nl/bibliotheek/knmipubWR/WR2009-05.pdf

Bindoff N, Willebrand J, Artale V, Cazenave A, Gregory J, Gulev S, Hanawa K, Le Qu C, Levitus S, Nojiri Y, Shum CK, Talley LD, Unnikrishnan A (2007) Observations: oceanic climate change and sea level. In: Solomon S, Qin D, Manning M, Chen Z, Marquis M, Averyt KB, Tignor M, Mille HL (eds) Climate Change 2007: The Physical Science Basis. Contribution of Working Group 1 to the Fourth Assessment Report of the Intergovernmental Panel on Climate Change. Cambridge University Press, Cambridge

Cazenave A, Nerem RS (2004) Present-day sea-level change: observations and causes. Rev Geophys 42:RG3001. doi:10.1029/2003RG000139

Cazenave A, Dominh K, Guinehut S, Berthier E, Llovel W, Ramilien G, Ablain M, Larnicol G (2009) Sea level budget over 2003-2008. A reevaluation from GRACE space gravimetry, satellite altimetry and ARGO. Glob Planet Change 65:83-88

Chen JL, Wilson CR, Blankenship DD, Tapley BD (2006) Antarctic mass rates from GRACE. Geophys Res Lett 33:L11,502. doi:10.1029/2006GL026369

Clark J, Primus JA (1988) Sea level change resulting from future retreat of ice sheets: an effect of $\mathrm{CO} 2$ warming of the climate. In: Tooley MJ, Shennan I (eds) Sea level changes. Basil Blackwell Publ., Intitute of British Geographers Special Publication, pp 356-370

Clark PU, Huybers P (2009) Global change: interglacial and future sea level. Nature 462:856-857. doi:10.1038/462856a

Cook AJ, Fox AJ, Vaughan DG, Ferrigno DG (2005) Retreating Glacier fronts on the Antarctic Peninsula over the past half-century. Science 308:541-544

Davis CH, Yonghong L, McConnell JR, Frey MM, Hanna E (2005) Snowfall-driven growth in East Antarctic ice sheet mitigates recent sea-level rise. Science 308:1898-1901. doi:10.1126/ science. 1110662

Deltacommissie (2008) Working together with water: a living land builds for its future. Available from www.deltacommissie.com/doc/deltareport_full.pdf

Duplessy JC, Roche DM, Kageyama M (2007) The deep ocean during the last interglacial period. Science 316:89-91. doi:10.1126/science.1138582

Dyurgerov MB, Meier MF (2005) Glaciers and the changing earth system: a 2004 snapshot. Occasional Paper 58, University of Colorado, Institute of Arctic and Alpine Research. Available from http://instaar.colorado.edu/other/occ_papers.htm

Farrell WE, Clark JA (1976) On postglacial sea level. Geophys J Int 46:647-667. doi:10.1111/ j.1365-246X.1976.tb01252.x

Grinsted A, Moore JC, Jevrejeva S (2009) Reconstructing sea level from paleo and projected temperatures 200 to 2100 AD. Clim Dyn. doi:10.1007/s00382-008-0507-2

Helsen MM, van den Broeke MR, van de Wal RSW, van de Berg WJ, van Meijgaard E, Davis CH, Li Y, Goodwin I (2008) Elevation changes in Antarctica mainly determined by accumulation variability. Science 320:1626-1629. doi:10.1126/science.1153894

Holgate S, Jevrejeva S, Woodworth P, Brewer S (2007) Comment on “A Semi-Empirical Approach to Projecting Future Sea level Rise". Science 317. doi:10.1126/science.1140942

Holland DM, Thomas RH, de Young B, Ribergaard MH, Lyberth B (2008) Acceleration of Jakobshavn Isbrae triggered by warm subsurface ocean waters. Nat Geosci 1:659-664. doi:10.1038/ngeo316

Houghton JT, Meira Filho LG, Callender BA, Harris N, Kattenberg A, Maskell K (eds) (1995) Climate change 1995: the science of climate change. Contribution of working group 1 to the second assessment report of the intergovernmental panel on climate change. Cambridge University Press, UK

Houghton JT, Ding Y, Griggs DJ, Noguer M, van der Linden PJ, Dai X, Maskell K, Johnson CA (eds) (2001) Climate change 2001: the scientific basis. Contribution of working group I to the third assessment report of the intergovernmental panel on climate change. Cambridge University Press, $881 \mathrm{pp}$

Howat IM, Joughin I, Scambos TA (2007) Rapid Changes in Ice Discharge from Greenland Outlet Glaciers. Science 315:1559-1561, doi:10.1126/science.1138478 
Jansen E, Overpeck J, Briffa KR, Duplessy JC, Joos F, Masson-Delmotte V, Olago D, Otto-Bliesner B, Peltier WR, Rahmstorf S, Ramesh R, Raynaud D, Rind D, Solomina O, Villalba R, Zhang D (2007) Palaeoclimate. In: Solomon S, Qin D, Manning M, Chen Z, Marquis M, Averyt KB, Tignor M, Mille HL (eds) Climate change 2007: the physical science basis. Contribution of working group 1 to the fourth assessment report of the intergovernmental panel on climate change. Cambridge University Press, Cambridge

Jenkins A, Dutrieux P, Jacobs SS, McPhail SD, Perrett JR, Webb AT, White D (2010) Observations beneath Pine Island Glacier in West Antarctica and implications for its retreat. Nat Geosci 3:468472. doi:10.1038/ngeo890

Jevrejeva S, Moore JC, Grinsted A (2010) How will sea level respond to changes in natural and anthropogenic forcings by 2100? Geophys Res Lett 37:L07,703. doi:10.1029/2010GL042947

Joughin I, Rignot E, E RC, Lucchitta BK, Bohlander J (2003) Timing of recent accelerations of Pine Island Glacier. Geophys Res Lett 30:1706

Joughin I, Abdalati W, Fahnestock M (2004) Large fluctuations in speed on Greenlands Jakobshavn Isbrae glacier. Nature 432:608-610. doi:10.1038/nature03130

Joughin I, Das SB, King MA, Smith BE, Howat IM, Moon T (2008a) Seasonal speedup along the Western Flank of the Greenland Ice Sheet. Science 320:781-783. doi:10.1126/science. 1153288

Joughin I, Howat I, Alley RB, Ekstrom G, Fahnestock M, Moon T, Nettles M, Truffer M, Tsai VC (2008b) Ice-front variation and tidewater behavior on Helheim and Kangerdlugssuaq Glaciers, Greenland. J Geophys Res 113:F01,004. doi:10.1029/2007JF000837

Kabat P, Fresco LO, Stive MJF, Veerman CP, van Alphen JSLJ, Parmet BWAH, Hazeleger W, Katsman CA (2009) Dutch coasts in transition. Nat Geosci 2:7. doi:10.1038/ngeo572

Katsman CA, Church JA, Kopp RE, Kroon D, Oppenheimer M, Plag HP, Rahmstorf S, Ridley J, von Storch H, Vaughan DG, van der Wal RSW (2008a) High-end projection for local sea level rise along the Dutch coast in 2100 and 2200. In: Exploring high-end climate change scenarios for flood protection of the Netherlands. KNMI/Alterra, The Netherlands, pp 15-81. Available from http://www.knmi.nl/bibliotheek/knmipubWR/WR2009-05.pdf

Katsman CA, Hazeleger W, Drijfhout SS, van Oldenborgh GJ, Burgers G (2008b) Climate scenarios of sea level rise for the northeast Atlantic Ocean: a study including the effects of ocean dynamics and gravity changes induced by ice melt. Clim Change. doi:10.1007/s10584-008-9442-9

Khan SA, Wahr J, Stearns LA, Hamilton GS, van Dam T, Larson KM, Francis O (2007) Elastic uplift in southeast Greenland due to rapid ice mass loss. Geophys Res Lett 34:L21701. doi:10.1029/2007GL031468

Kooi H, Johnston P, Lambeck K, Smither C, Molendijk R (1998) Geological causes of recents ( 100 yr) vertical land movement in the Netherlands. Tectonophysics 299:297-316

Kopp RE, Simons FJ, Mitrovica JX, Maloof AC, Oppenheimer M (2009) Probabilistic assessment of sea level during the last interglacial. Nature 462:863-867. doi:10.1038/nature08686

Krabill W, Abdalati W, Frederick E, Manizade S, Martin C, Sonntag J, Swift R, Thomas R, Wright W, Yungel J (2000) Greenland ice sheet: high-elevation balance and peripheral thinning. Science 289:428-530

Krabill W, Hanna E, Huybrechts P, Abdalati W, Cappelen J, Csatho B, Frederick E, Manizade S, Martin C, Sonntag J, Swift R, Thomas R, Yungel J (2004) Greenland ice sheet: increased coastal thinning. Geophys Res Lett 31:L24,402. doi:10.1029/2004GL021533

Landerer FW, Jungclaus JH, Marotzke J (2007) Regional dynamic and steric sea level change in response to the IPCC-A1B scenario. J Phys Oceanogr 37:296-312

Laurian A, Drijfhout S (2010) Response of the South Atlantic circulation to an abrupt Atlantic THC collapse. Clim Dyn. doi:10.1007/s00382-010-0890-3

Lenderink G, Buishand TA, van Deursen WPA (2007) Estimation of future discharges of the river Rhine using two scenario methodologies: direct versus delta approach. Hydrol Earth Syst Sci 11:1145-1159

Lenton TM (2006) Climate change to the end of the millennium. Clim Change 76:7-29

Levermann A, Griesel A, Hofmann M, Montoya M, Rahmstorf S (2004) Dynamic sea level changes following changes in the thermohaline circulation. Clim Dyn 24:347-354

Lisiecki LE, Raymo ME (2005) A Pliocene-Pleistocene stack of 57 globally distributed benthic 180 records. Paleoceanography 20:1-17

Lowe JA, Gregory JM (2005) The effects of climate change on storm surges around the United Kingdom. Philos Trans R Soc 363:1313-1328 
Luthcke SB, Zwally HJ, Abdalati W, Rowlands DD, Ray RD, Nerem RS, Lemoine FG, McCarthy JJ, Chinn DS (2006) Recent Greenland ice mass loss by drainage system from satellite gravity observations. Science 314:1286-1289. doi:10.1126/science.1130776

Meehl G, Stocker TF, Collins WD, Friedlingstein P, Gaye AT, Gregory JM, Kitoh A, Knutti R, Murphy JM, Noda A, Raper SCB, Watterson IG, Weaver AJ, Zhao ZC (2007a) Global climate projections. In: Solomon S, Qin D, Manning M, Chen Z, Marquis M, Averyt KB, Tignor M, Mille HL (eds) Climate change 2007: the physical science basis. Contribution of Working Group 1 to the fourth assessment report of the Intergovernmental Panel on Climate Change. Cambridge University Press, Cambridge

Meehl GA, Covey C, Delworth T, Latif M, McAvaney B, Mitchell JFB, Stouffer RJ, Taylor KE (2007b) The WCRP CMIP3 multimodel dataset: a new era in climate change research. Bull Am Meteorol Soc 88:1383-1394

Meier MF, Dyurgerov MB, Rick UK, O’Neel S, Pfeffer WT, Anderson RS, Anderson SP, Glazovsky AF (2007) Glaciers dominate eustatic sea-level ris ein the 21st century. Science 317:1064-1067. doi:10.1126/science.1143906

Mercer JH (1978) West Antarctic ice sheet and CO2 greenhouse effect: a threat of disaster. Nature 271:321-325

Middelkoop H, Daamen K, Gellens D, Grabs W, Kwadijk JCJ, Lang H, Parmet BWAH, Schadler B, Schulla J, Wilke K (2001) Impact of climate change on hydrological regimes and water resources management in the Rhine basin. Clim Change 49:105-128

Milne GA, Gehrels WR, Hughes CW, Tamisiea ME (2009) Identifying the causes for sea-level change. Nat Geosci 2:471-478. doi:10.1038/NGEO544

Mitrovica JX, Tamisiea ME, Davis JL, Milne GA (2001) Recent mass balance of polar ice sheets inferred from patterns of global sea level change. Nature 409:1026-1029

Nick FM, Vieli A, Howat IM, Joughin I (2009) Large-scale changes in Greenland outlet glacier dynamics triggered at the terminus. Nat Geosci 2:110-114. doi:10.1038/NGEO394

Ohmura A (2004) Cryosphere during the twentieth century, the state of the planet. IUGG Geophys Monogr 150:239-257

Otto-Bliesner BL, Marshall SJ, T OJ, Miller GH, Hu A, CAPE Last Interglaciation Project members (2006) Simulating Arctic climate warmth and ice-field retreat in the last interglaciation. Science 311:1751-1753. doi:10.1126/science. 1120808

Overpeck JT, Otto-Bliesner BL, Miller GH, Muhs DR, Alley RB, Kiehl JT (2006) Paleoclimatic evidence for future ice-sheet instability and rapid sea-level rise. Science 311:1747-1750. doi:10.1126/science.1115159

Pfeffer WT (2007) A simple mechanism for irreversible tidewater glacier retreat. J Geophys Res 112:F03S25. doi:10.1029/2006JF000590

Pfeffer WT, Harper J, ONeel S (2008) Kinematic constraints on glacier contributions to 21st-century sea-level rise. Science 321:1340-1343

Plag HP, Juettner HU (2001) Inversion of global tide gauge data for present day ice load changes. Proceedings of the second international symposium on environmental research in the Arctic and 5th Ny-Alesund scientific seminar, pp 301-317

Pritchard H, Vaughan DG (2007) Widespread acceleration of tide water glaciers on the Antarctic Peninsula. J Geophys Res 112:F03S29. doi:10.1029/2006JF000597

Pritchard H, Arthern RJ, Vaughan DG, Edwards LA (2009) Extensive dynamic thinning on the margins of the Greenland and Antarctic ice sheets. Nature 461. doi:10.1038/nature08471

Radic V, Hock R (2010) Regional and global volumes of glaciers derived from statistical upscaling of glacier inventory data. Geophys Res Letters 115:F01,010. doi 10.1029/2009JF001373

Rahmstorf S (2007a) A semi-empirical approach to projecting future sea level rise. Science 315:368370. doi:10.1126/science. 1135456

Rahmstorf S (2007b) Response to Comments on "A Semi-Empirical Approach to Projecting Future Sea level Rise”. Science 317:1866. dOI:10.1126/science.1141283

Ramillien G, Lombard A, Cazenave A, Ivins ER, Llubes M, Remy F, Biancale R (2006) Interannual variations of the mass balance of the Antarctica and Greenland ice sheets from GRACE. Glob Planet Change 53:198-208

Raper SCB, Braithwaite RJ (2005) The potential for sea level rise: new estimates from glacier and ice cap area and volume distribution. Geophys Res Lett 32:L05,502. doi:10.1029/2004GL02181

Rignot EG, Kanagaratnam P (2006) Changes in the Velocity Structure of the Greenland Ice Sheet. Science 311:986-990 
Rignot EG, Thomas RH (2002) Mass balance of polar ice sheets. Science 297:1502-1506

Rignot EG, Bamber J, van den Broeke M, Davis C, Li Y, van de Berg W, van Meijgaard E (2008) Recent Antarctic mass loss from radar interferometry and regional climate modelling. Nat Geosci 2:106-110. doi:10.1038/ngeo102

Rohling EJ, Grant K, Hemleben C, Siddall M, Hoogakker BAA, Bolshaw M, Kucera M (2008) High rates of sea level rise during the last interglacial period. Nat Geosci 1:38-42. doi:10.1038/ngeo.2007.28

Scambos T, Bohlander JA, Shuman CA, Skvarca P (2004) Glacier acceleration and thinning after ice shelf collapse in the Larsen B embayment, Antarctica. Geophys Res Lett 31:L18,402. doi:10.1029/2004GL020670

Schmith T, Johansen S, Thejll P (2007) Comment on "A Semi-Empirical Approach to Projecting Future Sea level Rise". Science 317. doi:10.1126/science.1143286

Shabalova MV, van Deursen WPA, Buishand TA (2004) Assessing future discharge of the river Rhine using regional climate model integrations and a hydrological model. Clim Res 23:233-246

Shackleton NJ, Hall MA, Vincent E (2000) Phase relationships between millennial-scale events 64,000-24,000 years ago. Paleoceanography 15:565-569

Stammer D (2008) Response of the global ocean to Greenland and Antarctic ice melting. J Geophys Res 113:C06,022. doi:10.1029/2006JC004079

Sterl A, Severijns C, Dijkstra HA, Hazeleger W, van Oldenborgh G, van den Broeke M, Burgers G, van den Hurk B, van Leeuwen PJ, van Velthoven P (2008a) When can we expect extremely high surface temperatures? Geophys Res Lett 35:L14,703. doi:10.1029/2008GL034071

Sterl A, Weisse R, Lowe J, von Storch H (2008b) Winds and storm surges along the Dutch coast. In: Exploring high-end climate change scenarios for flood protection of the Netherlands. KNMI/Alterra, The Netherlands, pp 82-98. Available from http://www.knmi.nl/bibliotheek/ knmipubWR/WR2009-05.pdf

Sterl A, van den Brink HW, de Vries H, Haarsma R, van Meijgaard E (2009) An ensemble study of extreme North Sea storm surges in a changing climate. Ocean Sci 5:369-378. doi:10.5194/os-5-369-2009

Straneo F, Hamilton GS, Sutherland DA, Stearns LA, Davidson F, Hammill MO, Stenson GB, Rosing-Asvid A (2010) Rapid circulation of warm subtropical waters in a major glacial fjord in East Greenland. Nat Geosci 3:182-186. doi:10.1038/ngeo764

Thomas R, Rignot E, Casassa G, Kanagaratnam P, Acuna C, Akins T, Brecher H, Frederick E, Gogineni P, Krabil W, Manizade S, Ramamoorthy H, Rivera A, Russell R, Sonntag J, Swift R, Yungel J, Zwally J (2004) Accelerated Sea-Level Rise from West Antarctica. Science 306:255258. doi:10.1126/science. 1099650

Thomas R, Frederick E, Krabill W, Manizade S, Martin C (2006) Progressive increase in ice loss from Greenland. Geophys Res Lett 33:L10,503. doi:10.1029/2006GL026075

van de Wal RSW, Wild M (2001) Modelling the response of glaciers to climate change, applying volume-area scaling in combination with a high resolution GCM. Clim Dyn 18:359-366

van de Wal RSW, Boot W, van den Broeke M, Smeets CJPP, Reijmer CH, Donker JJA, Oerlemans J (2008) Large and rapid velocity changes in the ablation zone of the Greenland ice sheet. Science 321:111-113

van den Hurk BJJM, Klein Tank AMG, Lenderink G, van Ulden AP, van Oldenborgh GJ, Katsman CA, van den Brink HW, Keller F, Bessembinder JJF, Burgers G, Komen GJ, Hazeleger W, Drijfhout SS (2006) KNMI climate change scenarios 2006 for the Netherlands. Technical report WR-2006-01, KNMI. Available from www.knmi.nl/climatescenarios

van den Hurk BJJM, Klein Tank AMG, Lenderink G, van Ulden AP, van Oldenborgh GJ, Katsman CA, van den Brink HW, Keller F, Bessembinder JJF, Burgers G, Komen GJ, Hazeleger W, Drijfhout SS (2007) New climate change scenarios for the Netherlands. Water Sci Technol 56:2733. doi:10.2166/wst.2007.533

Vaughan DG (2006) Recent trends in melting conditions on the Antarctic Peninsula and their implications for ice-sheet mass balance. Arct Antarct Alp Res 38:147-152

Vaughan DG (2008) West Antarctic Ice Sheet collapse-the fall and rise of a paradigm. Clim Change 91:65-79. doi:10.1007/s10584-008-9448-3

Velicogna I (2009) Increasing rates of ice mass loss from the Greenland and Antarctic ice sheets revealed by GRACE. Geophys Res Lett 36:L19,503. doi:10.1029/2009GL040222

Velicogna I, Wahr J (2005) Greenland mass balance from GRACE. Geophys Res Lett 32:L18,505. doi:10.1029/2005GL023955

Velicogna I, Wahr J (2006a) Acceleration of Greenland ice mass loss in spring 2004. Nature 443:329_ 331 
Velicogna I, Wahr J (2006b) Measurements of time-variable gravity shows mass loss in Antarctica. Science 311:1754. doi:10.1126/science.1123785

Vellinga M, Wood RA (2002) Global climatic impacts of a collapse of the Atlantic thermohaline circulation. Clim Change 54:251-267

Vellinga P, Katsman CA, Sterl A, Beersma JJ, Church JA, Hazeleger W, Kopp RE, Kroon D, Kwadijk J, Lammersen R, Lowe J, Marinova N, Oppenheimer M, Plag HP, Rahmstorf S, Ridley J, von Storch H, Vaughan DG, van der Wal RSW, Weisse R (2008) Exploring high-end climate change scenarios for flood protection of The Netherlands. International scientific assessment carried out at request of the delta committee. Scientific Report WR-2009-05. KNMI/Alterra, The Netherlands. Available from http://www.knmi.nl/bibliotheek/knmipubWR/WR2009-05.pdf

Vermeer M, Rahmstorf S (2009) Global sea level linked to global temperature. Proc Natl Acad Sci USA 106:21,527-21,532. doi:10.1073/pnas.0907765106

von Storch H, Zorita E, Gonzalez-Rouco F (2009) Relationships between global mean sea-level and global mean temperature and heat-flux in a climate simulation of the past millennium. Ocean Dyn 58:227-236. doi:10.1007/s10236-088-0142-9

WASA-Group (1998) Changing waves and storms in the Northeast Atlantic? Bull Am Meteorol Soc 79:741-760

Wigley TML (2005) The climate change commitment. Science 307:1766-1769

Wingham DJ, Ridout AJ, Scharroo R, Arthern RJ, Shum CK (1998) Antarctic elevation change from 1992 to 1996 . Science 282:456-458. doi:10.1126/science.282.5388.456

Wingham DJ, Shepherd A, Muir A, Marshall G (2006) Mass balance of the Antarctic ice sheet. Philos Trans R Soc 364:1627-1635

Woodward RS (1888) On the form and position of mean sea level. US Geol Surv Bull 48:87-170

Woth K (2005) North Sea storm surge statistics based on projections in a warmer climate: how important are driving GCM and the chosen emission scenario? Geophys Res Lett 32:L22,708. doi:10.1029/2005GL023762

Wouters B, Chambers D, Schrama E (2008) GRACE observes small-scale mass loss in Greenland. Geophys Res Lett 35:L20,501. doi:10.1029/2008GL034816

Yin J, Schlesinger ME, Stouffer RJ (2009) Model projections of rapid sea-level rise on the northeast coast of the United States. Nat Geosci 2:262-266. doi:10.1038/NGEO462

Zagwijn WH (1983) Sea level changes in The Netherlands during the Eemian. Geol Mijnb 62:437450

Zagwijn WH (1996) An analysis of Eemian climate in western and central Europe. Quat Sci Rev 15:451-469

Zwally HJ, Abdalati W, Herring T, Larson K, Saba J, Steffen K (2002) Surface meltininduced acceleration of greenland ice-sheet flow. Science 218:218-222

Zwally H, Giovinetto M, Li J, Cornejo H, Beckley M, Brenner A, co-authors (2005) Mass changes of the Greenland and Antarctic ice sheets and shelves and contributions to sea level rise: 1992-2002. J Glaciol 51:509-527 